\title{
Organic aerosol components observed in Northern Hemispheric datasets from Aerosol Mass Spectrometry
}

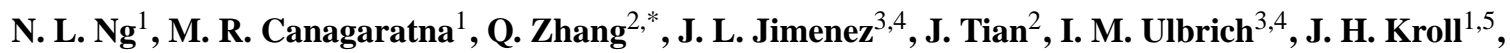 \\ K. S. Docherty ${ }^{3,4}$, P. S. Chhabra ${ }^{6}$, R. Bahreini ${ }^{3,7}$, S. M. Murphy ${ }^{7}$, J. H. Seinfeld ${ }^{6}$, L. Hildebrandt ${ }^{8}$, N. M. Donahue ${ }^{8}$, \\ P. F. DeCarlo ${ }^{3,9,10}$, V. A. Lanz ${ }^{10}$, A. S. H. Prévôt ${ }^{10}$, E. Dinar ${ }^{11}$, Y. Rudich ${ }^{11}$, and D. R. Worsnop ${ }^{1}$ \\ ${ }^{1}$ Aerodyne Research, Inc. Billerica, MA, USA \\ ${ }^{2}$ Atmospheric Sciences Research Center, State University of New York, Albany, NY, USA \\ ${ }^{3}$ CIRES, University of Colorado, Boulder, CO, USA \\ ${ }^{4}$ Department of Chemistry and Biochemistry, University of Colorado, Boulder, CO, USA \\ ${ }^{5}$ Department of Civil and Environmental Engineering, Massachusetts Institute of Technology, Cambridge, MA, USA \\ ${ }^{6}$ Department of Chemical Engineering, California Institute of Technology, Pasadena, CA, USA \\ ${ }^{7}$ NOAA, Earth System Research Laboratory, Boulder, CO, USA \\ ${ }^{8}$ Center for Atmospheric Particle Studies, Carnegie Mellon University, Pittsburgh, PA, USA \\ ${ }^{9}$ Department of Atmospheric and Oceanic Science, University of Colorado, Boulder, CO, USA \\ ${ }^{10}$ Laboratory of Atmospheric Chemistry, Paul Scherrer Institut, Villigen, Switzerland \\ ${ }^{11}$ Department of Environmental Sciences, Weizmann Institute of Science, Rehovot 76100, Israel \\ *now at: Department of Environmental Toxicology, University of California, Davis, CA, USA
}

Received: 27 November 2009 - Published in Atmos. Chem. Phys. Discuss.: 23 December 2009

Revised: 14 April 2010 - Accepted: 29 April 2010 - Published: 20 May 2010

\begin{abstract}
In this study we compile and present results from the factor analysis of 43 Aerosol Mass Spectrometer (AMS) datasets (27 of the datasets are reanalyzed in this work). The components from all sites, when taken together, provide a holistic overview of Northern Hemisphere organic aerosol $(\mathrm{OA})$ and its evolution in the atmosphere. At most sites, the OA can be separated into oxygenated OA (OOA), hydrocarbon-like OA (HOA), and sometimes other components such as biomass burning OA (BBOA). We focus on the OOA components in this work. In many analyses, the OOA can be further deconvolved into low-volatility OOA (LV-OOA) and semi-volatile OOA (SV-OOA). Differences in the mass spectra of these components are characterized in terms of the two main ions $m / z 44\left(\mathrm{CO}_{2}^{+}\right)$and $m / z 43$ (mostly $\mathrm{C}_{2} \mathrm{H}_{3} \mathrm{O}^{+}$), which are used to develop a new mass spectral diagnostic for following the aging of OA components in the atmosphere. The LV-OOA component spectra have higher $f_{44}$ (ratio of $m / z 44$ to total signal in the com-
\end{abstract}

Correspondence to: M. R. Canagaratna (mrcana@aerodyne.com) ponent mass spectrum) and lower $f_{43}$ (ratio of $m / z 43$ to total signal in the component mass spectrum) than SV-OOA. A wide range of $f_{44}$ and O:C ratios are observed for both LV-OOA $(0.17 \pm 0.04,0.73 \pm 0.14)$ and SV-OOA $(0.07 \pm 0.04$, $0.35 \pm 0.14)$ components, reflecting the fact that there is a continuum of OOA properties in ambient aerosol. The OOA components (OOA, LV-OOA, and SV-OOA) from all sites cluster within a well-defined triangular region in the $f_{44} \mathrm{vs}$. $f_{43}$ space, which can be used as a standardized means for comparing and characterizing any OOA components (laboratory or ambient) observed with the AMS. Examination of the OOA components in this triangular space indicates that OOA component spectra become increasingly similar to each other and to fulvic acid and HULIS sample spectra as $f_{44}$ (a surrogate for O:C and an indicator of photochemical aging) increases. This indicates that ambient OA converges towards highly aged LV-OOA with atmospheric oxidation. The common features of the transformation between SV-OOA and LV-OOA at multiple sites potentially enable a simplified description of the oxidation of $\mathrm{OA}$ in the atmosphere. Comparison of laboratory SOA data with ambient OOA indicates

Published by Copernicus Publications on behalf of the European Geosciences Union. 
that laboratory SOA are more similar to SV-OOA and rarely become as oxidized as ambient LV-OOA, likely due to the higher loadings employed in the experiments and/or limited oxidant exposure in most chamber experiments.

\section{Introduction}

Organic aerosols (OA) constitute a substantial fraction (20$90 \%$ ) of submicron aerosols worldwide and a full understanding of their sources, atmospheric processing, and properties is important to assess their impacts on climate, human health, and visibility (Kanakidou et al., 2005; Zhang et al., 2007; Kroll and Seinfeld, 2008; Hallquist et al., 2009). The Aerodyne AMS provides quantitative data on inorganic and organic aerosol species in submicron non-refractory aerosol particles with high-time resolution. In recent years, several techniques have been employed to deconvolve the mass spectra of the organic aerosols acquired with the AMS including custom principal component analysis (CPCA) (Zhang et al., 2005a), multiple component analysis (MCA) (Zhang et al., 2007), hierarchical cluster analysis (Marcolli et al., 2006), positive matrix factorization (PMF) (Paatero and Tapper, 1994; Paatero 1997; Lanz et al., 2007; Nemitz et al., 2008; Aiken et al., 2008; Aiken et al., 2009b; Ulbrich et al., 2009), and the Multilinear Engine (ME-2) (Lanz et al., 2008).

Multivariate analysis by Zhang et al. (2007) showed that $\mathrm{OA}$ at multiple sites can be described by two main components: hydrocarbon-like organic aerosol (HOA) and oxygenated organic aerosol (OOA). Biomass burning OA (BBOA) and other local primary sources have also been observed (Jimenez et al., 2009). OOA accounts for a large fraction $(72 \pm 21 \%)$ of the total organic mass at many locations (Zhang et al., 2007; Jimenez et al., 2009). Studies from multiple locations show that the HOA component correlates well with primary tracers such as $\mathrm{CO}$ and $\mathrm{NO}_{\mathrm{x}}$ (e.g. Zhang et al., 2005b; Lanz et al., 2007; Aiken et al., 2009b; Ulbrich et al., 2009) and can be considered as a surrogate of combustion primary $\mathrm{OA}(\mathrm{POA})$. BBOA correlates with acetonitrile, levoglucosan, and potassium, and can be considered a surrogate of BB POA (Aiken et al., 2009a, b). The OOA component has been shown to be a good surrogate of secondary OA (SOA) in multiple studies, correlating well with secondary species such as $\mathrm{O}_{3}$ and $\mathrm{O}_{\mathrm{x}}$ (de Gouw et al., 2005; Zhang et al., 2005a, b, 2007; Volkamer et al., 2006; Lanz et al., 2007; Herndon et al., 2008).

In many analyses, two types of OOA have been identified. The two broad subtypes differ in volatility and degree of oxidation (Jimenez et al., 2009), as indicated by the ratio of $m / z 44$ to total signal in the component mass spectrum $\left(f_{44}\right)$. The more oxidized component (higher $f_{44}$ ) has previously been referred to as OOA-1 while the less oxidized component (lower $f_{44}$ ) has previously been referred to as OOA-2 (Lanz et al., 2007; Aiken et al., 2008, 2009b; Ne- mitz et al., 2008; Ulbrich et al., 2009). In those studies the OOA-1 represented the more oxidized, aged aerosols and the OOA-2 represented the less oxidized, fresher secondary organic species. Temporal correlations with sulfate and nitrate (Lanz et al., 2007; Ulbrich et al., 2009) as well as direct volatility measurements (Huffman et al., 2009) in those studies further showed that OOA-1 is less volatile than OOA-2. Since the OOA-1 and OOA-2 terminology does not convey the known physiochemical properties of these OOA subcomponents, in the following discussion we will refer to these subcomponents as low-volatility OOA (LV-OOA) and semivolatile OOA (SV-OOA), respectively. It is important to note that the assignment of LV-OOA and SV-OOA to the components identified at each site is not absolute, meaning that the LV-OOA at one site does not have the same composition as in another site. This is an expected result since factor analysis has been applied separately to each site. Thus here the terminology for the OOA subtypes is relative for each site (i.e., at each site the component with a higher $f_{44}$ is referred to as LV-OOA and the component with a lower $f_{44}$ is referred to as SV-OOA regardless of the absolute values of $f_{44}$ ). An absolute volatility scale for LV-OOA and SV-OOA is being investigated (e.g. Faulhaber et al., 2009; Cappa et al., 2009) but requires a better understanding of the volatility measurements of ambient aerosols (e.g., with thermodenuders).

The goal of this study is to compare and contrast the OOA components identified in multiple field studies in order to better characterize the sources and evolution of OA in the atmosphere. We present results from the factor analysis of 43 AMS datasets. 27 of the datasets, which encompass a majority of the sites in Zhang et al. (2007), are reanalyzed as part of this work. We focus mainly on the OOA component and the reanalysis allows for further deconvolution of the total OOA component reported by Zhang et al. (2007) into LV-OOA and SV-OOA components. The OA components resulting from this work were used by Jimenez et al. (2009) to form the basis of a modeling framework that links oxidation and volatility to capture the evolution of OA in the atmosphere. In this manuscript we combine the factor analysis results from the ambient datasets together to obtain a holistic view of how the AMS ambient component mass spectra change across environments with different sources and aerosol processes. The common features of the component spectra are used to develop a new mass spectral diagnostic for following the atmospheric aging of OA components in the atmosphere. Finally, since the AMS has been employed in many laboratory experiments over the years, a series of chamber data (both published and unpublished) are also integrated and compared to the ambient data. Chamber data provide the basis for simulating SOA formation in the atmosphere. Hence, it is important to evaluate whether the results from chamber experiments are representative of the atmosphere; similarities and differences between ambient OOA and laboratory SOA are examined and discussed. 


\section{Method}

The organic aerosol data have been obtained with the Aerodyne quadrupole mass aerosol spectrometer (Q-AMS), the compact time-of-flight mass spectrometer (C-ToF-AMS), or the high-resolution ToF-AMS (HR-ToF-AMS). The instrument design and operation of each version of the AMS has been described in detail by Jayne et al. (2000), Drewnick et al. (2005), and DeCarlo et al. (2006), respectively, and reviewed by Canagaratna et al. (2007). Factor analyses of the data from Riverside, CA, Whistler (Canada), and Mexico City (both ground and aircraft data) are based on high resolution (HR) data from HR-ToF-AMS, while analyses for all other locations are based on unit mass resolution (UMR) data. The details (locations, times, previous publications, etc.) of all datasets included in this study are given in the supplementary material.

In this work we present factor analysis results from 43 AMS datasets. As part of this work, we performed PMF (Paatero and Tapper, 1994; Paatero, 1997) based factor analysis of the organic aerosol mass spectra observed at 27 of the sites. For some of the urban downwind/rural/remote sites, a hybrid of PMF/MCA approach is employed (Cottrell et al., 2008; Nemitz et al., 2008). The factor analyses of the remaining 16 sites were performed previously and the results are discussed in more detail in the corresponding publications: Beijing (Sun et al., 2009), Riverside (Docherty et al., 2008; Huffman et al., 2009), Mexico City (Aiken et al., 2008, 2009a, b; DeCarlo et al., 2009), Pittsburgh (Zhang et al., 2005a, b; Ulbrich et al., 2009), Thompson Farm, NH (Cottrell et al., 2008), Zurich (Lanz et al., 2007), Egbert (Slowik et al., 2010), Crete (Hildebrandt et al., 2010), and the great Alpine region (Lanz et al., 2009). For the sites in Lanz et al. (2009), both PMF and ME-2 are used. In contrast to PMF, ME-2 allows for a priori constraints (partial or total) on the mass spectra and/or time series of the factors (Paatero, 1999; Lanz et al., 2008).

PMF is a multivariate factor analysis technique developed by Paatero and Tapper (1994) and Paatero (1997) to solve the bilinear factor model $x_{i j}=\Sigma_{p} g_{i p} f_{p j}+e_{i j}$ where $x_{i j}$ are the measured values of $j$ species in $i$ samples, $P$ are factors comprised of constant source profiles $\left(f_{j}\right.$, mass spectra for AMS data) with varying contributions over the time period of the dataset ( $g_{i}$, time series), without any a priori assumptions of either mass spectral or time profile (Lanz et al., 2007; Ulbrich et al., 2009). PMF computes the solution by minimizing the summed least squares errors of the fit weighted with the error estimates of each data point. Solutions are also constrained to have non-negative values. The error weighting and non-negativity constraint result in more physically meaningful solutions that are easier to interpret compared to other receptor models.

The PMF2 executable version 4.2 in the robust mode (Paatero, 1997) is used together with a custom software tool (PMF Evaluation Tool (PET), Ulbrich et al., 2009) in this analysis. The analysis and input error calculations are performed following the procedures described by Ulbrich et al. (2009). The optimal number of PMF components is determined by carefully examining the scaled residuals, evaluating the component's diurnal cycles and factor correlations with external tracers (including $\mathrm{CO}, \mathrm{O}_{3}, \mathrm{NO}_{\mathrm{x}}, \mathrm{NO}_{\mathrm{y}}, \mathrm{SO}_{2}$, $\mathrm{NO}_{3}^{-}$, and $\mathrm{SO}_{4}^{2-}$, when available), and comparing the component spectra with source mass spectra from the AMS mass spectra database (Ulbrich et al., 2009). The PMF2 optimization algorithm starts from random initial conditions, which can be changed by varying the value of the SEED input parameter. Multiple solutions generated with different SEED values are carefully examined to explore the possibility of multiple local minima in the solutions. The uncertainty in component mass spectra and time series due to rotation ambiguity is also examined by performing PMF analysis over a range of FPEAK values. Overall, the effect of positive FPEAK is to create more near-zero values in the mass spectra and decrease the number of near-zero values in the time series; negative FPEAK values have the opposite effect (Ulbrich et al., 2009). For all sites, improved correlations with external tracers or mass spectra are not found for FPEAK values different from 0 . Thus the FPEAK $=0$ solutions, which bound the observed data most closely, are chosen for all the sites analyzed in this study.

Rotational ambiguity can be explored by examining the appearance and disappearance of zero values in the mass spectra and time series of the factors (Paatero, 2008). In typical ambient datasets, a priori information about component time points or fragment ions with true zero values is not known; thus, the appearance of unrealistic zero values in the mass spectra and time series of the solutions can be used to evaluate the most reasonable limits of the FPEAK parameter (Ulbrich et al., 2009). For a few sites where component mass spectra or time series are highly correlated, rotational ambiguity is more significant. The change in mass spectra with FPEAK is more dramatic in components with a smaller mass fraction, as they can change more without causing large changes in the residuals. For instance, in the Pittsburgh dataset (acquired in September 2002) studied by Ulbrich et al. (2009), the variation in $f_{44}$ and $f_{43}$ in the SV-OOA component across the range of retained solutions (FPEAK -1.6 to 1.0 ) was $\sim 30 \%$, for the LV-OOA component $\sim 2 \%$, and for the HOA component $\sim 5 \%$ (relative to the solution with FPEAK=0). In general, it is found that the component mass spectra and time series for most sites analyzed in this work do not vary drastically over the reasonable range of FPEAK chosen. For example, the relative uncertainties in OOA component mass spectra for $f_{44}$ and $f_{43}$ (these fragments will be discussed in detail in the following sections) are typically $<5 \%$. For the Lanz et al. (2009) sites, similar rotational uncertainties are observed except for sites with low $f_{44}$ in SV-OOA, where an absolute uncertainty of $\pm 5 \%$ is estimated. 

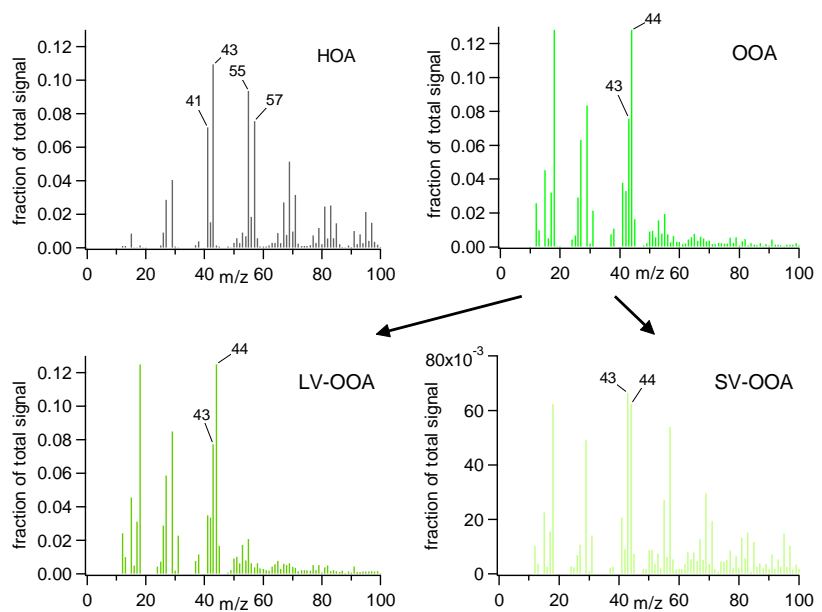

Fig. 1. Example mass spectra of the HOA, total OOA, LV-OOA and SV-OOA components identified from the Pittsburgh dataset (Zhang et al., 2007; Ulbrich et al., 2009). Note that the total OOA spectrum is not the average of the LV-OOA and SV-OOA because LV-OOA accounts for a much larger fraction (59\%) of OA than SV-OOA (10\%) in Pittsburgh.

\section{Results and discussion}

\subsection{Overview of organic aerosol components in the Northern Hemisphere}

Figure 1 shows example mass spectra of the HOA, total OOA, LV-OOA, and SV-OOA components identified from the Pittsburgh dataset (Zhang et al., 2005b; Ulbrich et al., 2009). The HOA component is distinguished by the clear hydrocarbon signatures in its spectrum, which are dominated by the ion series $\mathrm{C}_{n} \mathrm{H}_{2 n+1}^{+}$and $\mathrm{C}_{n} \mathrm{H}_{2 n-1}^{+}(m / z 27,29,41$, $43,55,57,69,71,83,85,97,99 \ldots)$ that are typical of hydrocarbons. The (total) OOA component is distinguished by the prominent $m / z 44\left(\mathrm{CO}_{2}^{+}\right)$in its spectrum and the lower relative intensity of higher mass fragments. Figure 2 shows the distribution of $f_{44}$ for the HOA, total OOA, LV-OOA, and SV-OOA components observed across the multiple sites. The top axis shows O:C ratios estimated using the $f_{44}$ of the PMF-resolved factor mass spectra and the correlation derived by Aiken et al. (2008). As seen in Fig. 2, both average $f_{44}$ and O:C for HOA components are generally very low. The OOA components, on the other hand, have higher $f_{44}$ and $\mathrm{O}: \mathrm{C}$ values of $0.14 \pm 0.04$ and $0.62 \pm 0.15$. The $f_{44}$ and $\mathrm{O}: \mathrm{C}$ ratios for all the LV-OOA and SV-OOA fall into two distinctive groups. The average $f_{44}$ and O:C ratio for SV-OOA components are $0.07 \pm 0.04$ and $0.35 \pm 0.14$, while those for the LV-OOA components are $0.17 \pm 0.04$ and $0.73 \pm 0.14$. It is important to note that a wide range of $f_{44}$ and O:C is observed around the average values for both the LV-OOA and SV-OOA components across all sites. This underscores the fact that neither the total OOA nor OOA subtypes are identical across the different sites. Some overlap between the high
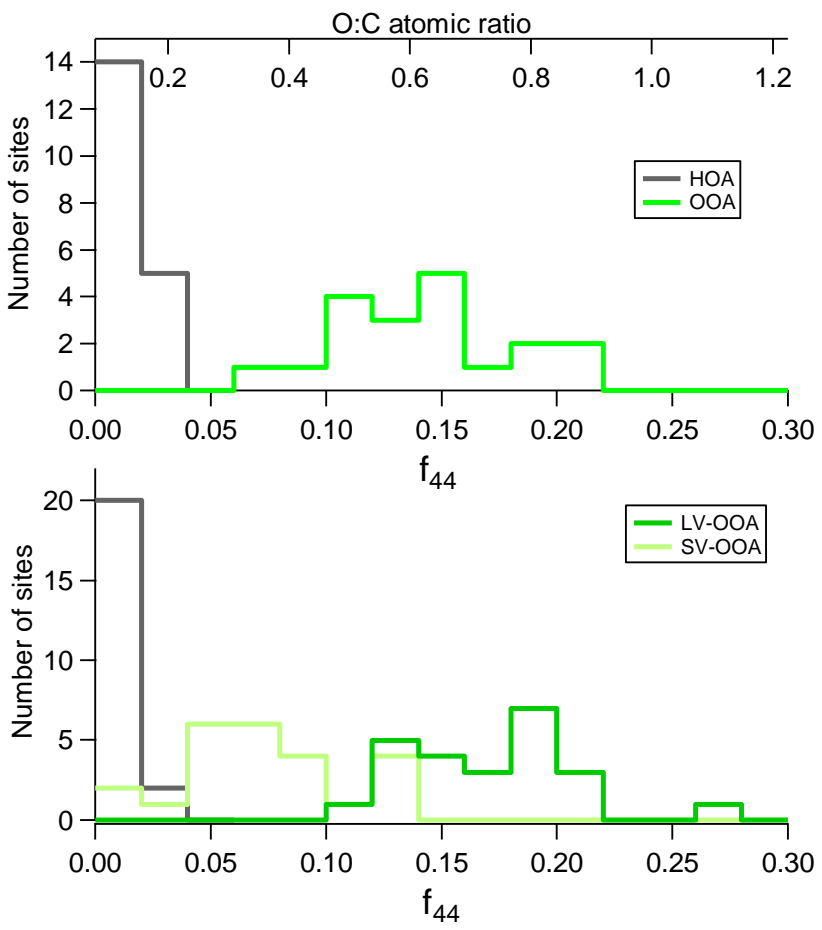

Fig. 2. Histograms showing the distribution of $f_{44}$ and estimated $\mathrm{O}: \mathrm{C}$ atomic ratios observed across the multiple sites. The top panel corresponds to sites where only one OOA component is obtained. The bottom panel corresponds to sites where both LV-OOA and SVOOA are resolved.

end of the SV-OOA range and the low end of the LV-OOA range occurs because the names SV-OOA and LV-OOA are relative for each site. Since an absolute scale to define volatility is not available, it is likely that the volatilities of the SVOOA and LV-OOA components in the overlapping region are not very different from each other.

The different $f_{44}$ and O:C values observed for the OOA components in Fig. 2 reflect the fact that there is a continuum of OOA properties in ambient aerosol. At each site this continuum is discretized into SV-OOA and LV-OOA components according to the details of the ambient OOA that is observed at that particular site. Figure 3 explicitly shows the $\mathrm{O}: \mathrm{C}$ atomic ratios and $f_{44}$ of the OOA, LV-OOA, and SVOOA components at each site. Similar to Zhang et al. (2007), the sites have been grouped according to their location as either being primarily urban or urban downwind/rural/remote. For some sites only one OOA factor is obtained while for others the range of oxidation is represented by both LVOOA and SV-OOA components. For sites where both LVOOA and SV-OOA are resolved, the average OOA O:C observed at any given time point can be reconstructed as a mass-weighted average of the LV-OOA and SV-OOA O:C. In Fig. 3, the mass-weighted average OOA component over the entire campaign is also shown for sites in which LV-OOA and SV-OOA are both resolved. The sites within each location 


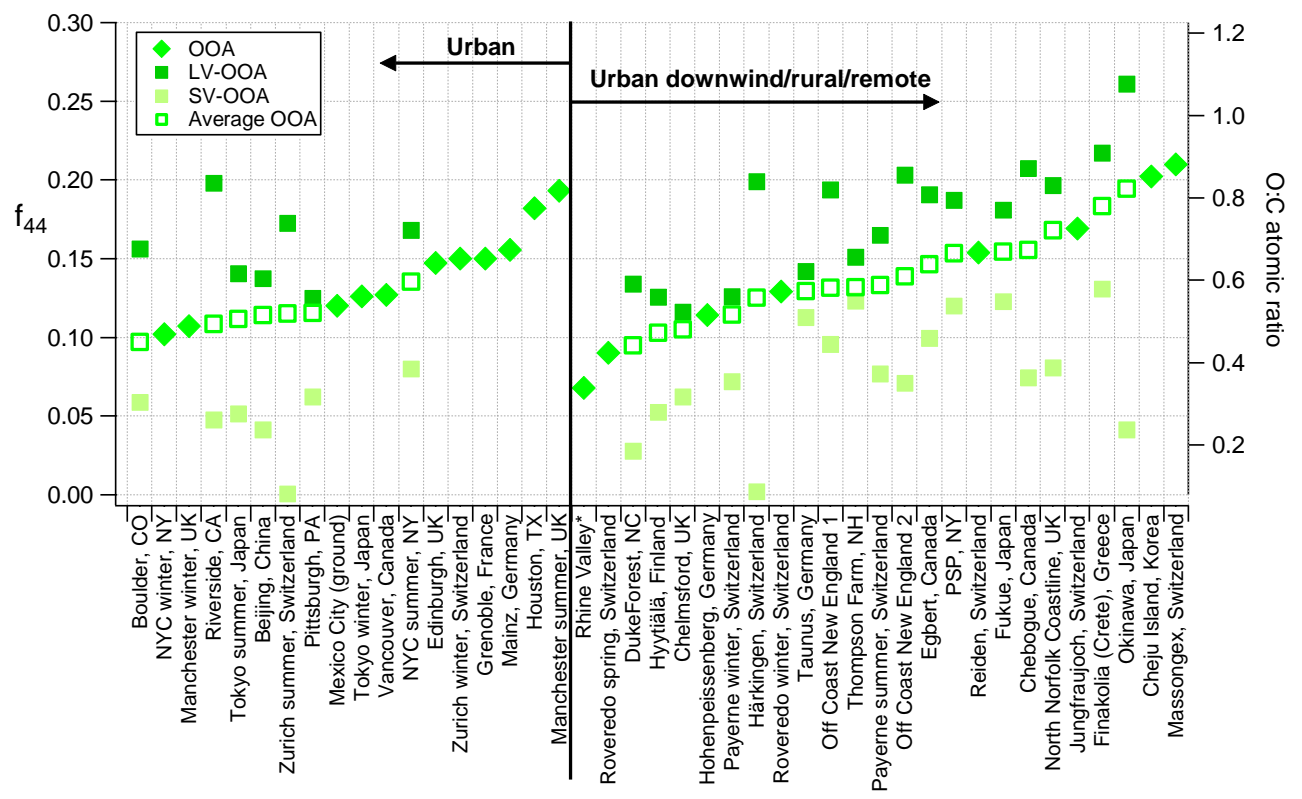

Fig. 3. $f_{44}$ and estimated O:C atomic ratios of the OOA, LV-OOA, and SV-OOA components at each site. The mass-weighted average OOA component over the entire campaign is also shown for sites in which LV-OOA and SV-OOA are both resolved. The sites within each location group are listed in increasing order of the $f_{44}$ and O:C ratio of the total OOA components and average OOA components. Uncertainties in $f_{44}$ of these components are discussed in the text. (Note: Rhine Valley* $=$ Switzerland, Austria, and Liechtenstein.)

group are listed in increasing order of the $f_{44}$ and O:C ratio of the total OOA component or the average OOA component (for sites with two OOA subtypes). The ability to resolve more than one OOA component depends on the dynamic range of various parameters for a given dataset, such as ambient temperature, the influence of different source regions and ages, and the intensity of the local/regional photochemistry. A single OOA is found for datasets in which the variability in the OOA mass spectrum is small and infrequent, which is typical for sites affected by very aged air masses. On the other hand, two OOA components are resolved for datasets where substantial and repeated changes in the total OOA mass spectrum appear. For instance, Lanz et al. (2009) and Jimenez et al. (2009) showed that the separation of OOA components into SV-OOA and LV-OOA is observed much more frequently in summer datasets than winter datasets, owing to more intense photochemistry, warmer temperatures, and larger temperature changes in summer.

The OOA measured at a given site is highly dependent on the meteorological and transport conditions, SOA precursors, and extent of photochemical aging observed at that site. In the urban Pittsburgh and Zurich datasets, for example, the observed range in OOA O:C is influenced by diurnal temperature fluctuations. These temperature changes separate the aged regional background LV-OOA component from the more local, fresher SV-OOA component (Lanz et al., 2007; Ulbrich et al., 2009). The remote/rural Chebogue Point (Nova Scotia, summer 2004) measurements show a range of $\mathrm{O}: \mathrm{C}$ that appear to reflect air masses of different ages and source regions. The more oxidized LV-OOA component at Chebogue correlates well with sulfate and an anthropogenically influenced US outflow factor extracted via principal component analysis of speciated measurements of volatile organic compounds (VOC) by PTR-MS and GC-MS (Millet et al., 2005; Holzinger et al., 2007; Williams et al., 2007). On the other hand, the less oxidized SV-OOA component is observed in the fresher air masses and correlates well with biogenic SOA tracer compounds (e.g., 2,3-pinene diol and pinonaldehyde - oxidation products of terpenes), suggesting that it is associated with SOA formed from biogenic hydrocarbons (Williams et al., 2007).

As discussed by Zhang et al. (2007), de Gouw et al. (2005), and Jimenez et al. (2009), cities act as point sources of HOA, which is quickly diluted in regional air dominated by OOA and overwhelmed by SOA production from the urban emissions. Thus, the relative contribution of OOA (compared to HOA) increases as air is transported from urban to urban downwind/remote/rural locations. As illustrated in Jimenez et al. (2009), increasing distance from an urban center is often correlated with an increase in photochemical aging and more oxidized OOA. This effect is not obvious in Fig. 3 (i.e., the total OOA and average OOA at urban downwind/rural/remote sites span a similar range of $\mathrm{O}: \mathrm{C}$ values as observed in urban sites). This highlights the complexity of the factors that determine the oxidation state of OOA at any given location. In addition to photochemical processing, meteorology and SOA precursors also affect the degree of oxidation of the OOA observed at a given location. 
For example, at many of the urban sites considered in this study, there is substantial inflow of regional aged OOA from outside the city because of meteorological conditions, resulting in an overall OA that is almost as oxidized as that found at more remote areas.

\subsection{Detailed comparison of SV-OOA and LV-OOA components}

Figure 1 shows representative mass spectra of LV-OOA and SV-OOA obtained in Pittsburgh, PA (Ulbrich et al., 2009). The different relative intensities of $m / z 44$ (mostly $\mathrm{CO}_{2}^{+}$) in the spectra are used to classify these two subcomponents. Previous studies have shown that $\mathrm{CO}_{2}^{+}$in AMS spectra can result from thermal decarboxylation of organic acid groups (Alfarra, 2004). Thermal decomposition of acids to yield $\mathrm{CO}_{2}$ is well known, and the $m / z 44\left(\mathrm{CO}_{2}^{+}\right)$fragment is found to be formed reproducibly by the thermal decarboxylation of oxo-, di- and polycarboxylic acids (Roberts and Caserio, 1964; Alfarra, 2004; Aiken et al., 2007; Takegawa et al., 2007), with dicarboxylic acids such as malic acid and oxalic acid resulting in a much higher $f_{44}$ than monoacids such as pyruvic acid (Alfarra, 2004). An acyl peroxide standard also gave rise to substantial signal at $m / z 44$ in the work of Aiken et al. (2007). Currently, there is no laboratory data showing that compounds with multiple functional groups (other than carboxylic acids and acyl peroxides) also give rise to substantial $f_{44}$ in the AMS. For instance, the mass spectra of methylglyoxal (with two carbonyl groups) and dioctyl sebacate (with two ester groups) have relatively weak signals at $m / z 44$ (Alfarra, 2004). In addition to $m / z 44$, the other key mass spectral difference that is typically observed between LV-OOA and SV-OOA components is the relative intensity of $m / z$ 43. Although $m / z 43$ can, in principle, correspond to $\mathrm{C}_{3} \mathrm{H}_{7}^{+}$or $\mathrm{C}_{2} \mathrm{H}_{3} \mathrm{O}^{+}$, HR data from Riverside, Mexico City (ground and flight), and Whistler indicate that the oxygenated fragment $\mathrm{C}_{2} \mathrm{H}_{3} \mathrm{O}^{+}$contributes a dominant fraction of the $m / z 43$ fragment ( $~ 81-99 \%)$ for ambient OOA, LVOOA, and SV-OOA components. Since organic acid groups likely decompose to give $m / z 44$, we hypothesize that the $\mathrm{C}_{2} \mathrm{H}_{3} \mathrm{O}^{+}$fragment at $m / z 43$ is dominated by non-acid oxygenates. According to McLafferty and Turecek (1993), the $\mathrm{m} / \mathrm{z} 43$ fragment is a prominent fragment from saturated carbonyl groups, but can also arise from other types of species. High resolution mass spectral studies of laboratory standards are needed to provide further insights.

As $m / z 44$ and $m / z 43$ are prominent peaks in the OOA, SV-OOA, and LV-OOA mass spectra and they are representative of different oxygen-containing functional groups, a detailed comparison of these mass fragments from all sites may yield some insights regarding the dynamic evolution of OOA in the atmosphere. Figure 4 shows the $f_{44}$ vs. $f_{43}$ for all the OOA components from different locations. Some of the differences in the $f_{44}$ and $f_{43}$ values shown in Fig. 4 can possibly arise from instrument-to-instrument variability. In princi-

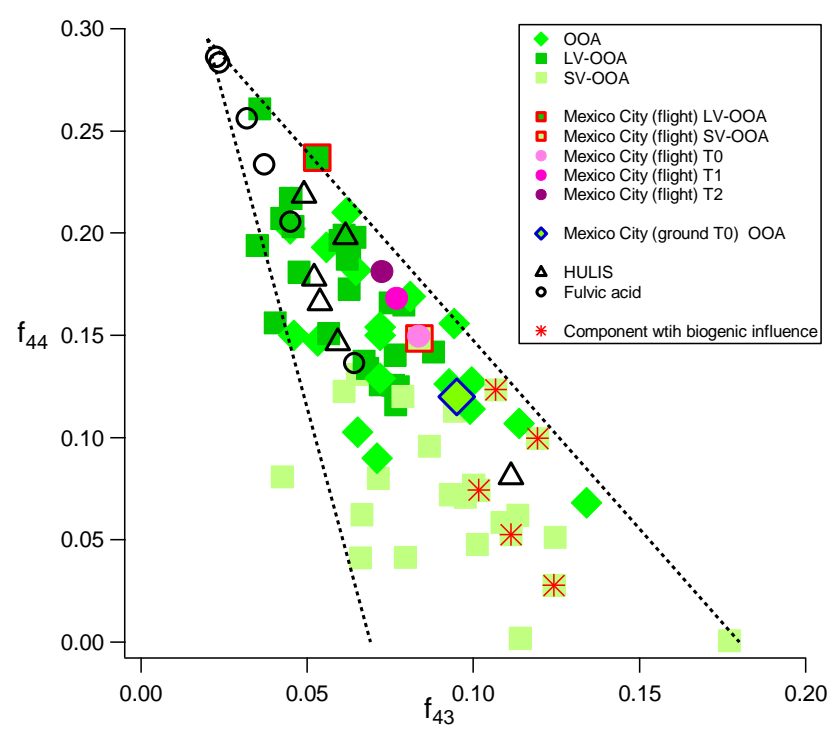

Fig. 4. $f_{44}$ vs. $f_{43}$ for all the OOA components from different sites, including Mexico city ground and flight data (Aiken et al., 2009b; Jimenez et al., 2009), as well as various HULIS (humic-like substances) and fulvic acid samples. The dotted lines are added to guide the eye and define the triangular space where ambient OOA components fall. The slope and intercept of the line on the left hand side are -6.0204 and 0.4154 ; the slope and intercept of the line on the right hand side are -1.8438 and 0.3319 , valid for $0.069 \leq \mathrm{x} \leq$ 0.18 , and $\mathrm{y} \leq 0.295$. Uncertainties in $f_{44}$ and $f_{43}$ of these components are discussed in the text.

ple, mass spectral data obtained by two different instruments can differ from each other due to differences in hardware and/or the operating conditions of the instrument. All of the UMR data points in Fig. 4 are obtained with Q-AMS instruments. Intercomparisons of UMR Q-AMS laboratory spectra observed by two different groups (Alfarra, 2004; Takegawa et al., 2007) for several diacids (malonic, succinic, glutaric, and adipic acid) show only small differences in $f_{44}$ and $f_{43}$ that are on the order of $2 \%$ (absolute). Thus, it is unlikely that this variability is enough to affect our interpretation of the general trends observed among the different OOAs.

Since photochemical aging leads to an increase in $f_{44}$ (Alfarra et al., 2004; de Gouw et al., 2005; Aiken et al., 2008; Kleinman et al., 2008), the $f_{44}$ axis can be considered as an indicator of atmospheric aging. The Mexico City flight and ground data points in Fig. 4 provide a good example for illustrating the increase in $f_{44}$ with photochemical aging. Figure 4 shows the Mexico City ground site (T0) and the aircraft data at T0 (above urban area), $\mathrm{T} 1$ (30 km downwind, $\sim 3 \mathrm{~h}$ transport from the urban area), and T2 $(60 \mathrm{~km}$ downwind, $\sim 6 \mathrm{~h})$. The photochemical ages of air masses sampled above these sites increase with distance away from the urban area. The average OOA components for each of these locations clearly indicate the increase in $f_{44}\left(\mathrm{~T} 0_{\text {ground }}<\mathrm{T} 0_{\text {aircraft }}<\mathrm{T} 1_{\text {aircraft }}<\mathrm{T} 2_{\text {aircraft }}\right)$ with photochemical age. 


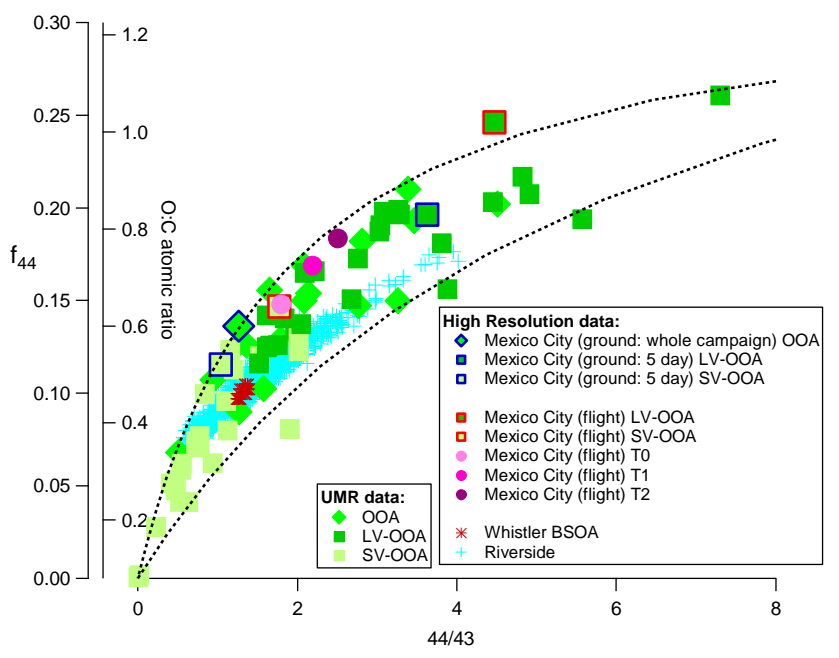

Fig. 5. $f_{44}$ and O:C vs. $44 / 43$ for all the OOA components from different sites, including Mexico city ground (whole campaign and 5 day) (Aiken et al., 2008; Aiken et al., 2009b) and flight data (Jimenez et al., 2009). Also shown are the time-dependent data of the OOA components at Riverside, as well as data obtained during a biogenics SOA event at Whistler. For the UMR data, O:C is estimated using the $f_{44}$ of the PMF-resolved factor mass spectra and the correlation derived by Aiken et al. (2008); for the HR data the $\mathrm{O}: \mathrm{C}$ is directly determined by elemental analysis (hence the $f_{44}$ axis does not apply to the HR data). The two dotted curves represent the mathematical transformation of the two lines in Fig. 4.

Figure 4 also shows $f_{44}$ and $f_{43}$ from the AMS mass spectra of various HULIS (humic-like substances) and fulvic acid samples, generated by atomization of the aqueous samples into the AMS. The HULIS samples, composed of high molecular weight polycarboxylic acids, are extracted from various ambient filter samples (Dinar et al., 2006). The fulvic acid samples are from a commercially available standard of humic substance (Suwannee River Fulvic Acid, SRFA), including the bulk sample as well as various sizefractionated samples obtained by microfiltration (Dinar et al., 2006; Graber and Rudich, 2006).

A key feature of Fig. 4 is that the ambient OOA components from all the sites cluster within a well-defined triangular region of the plot. The dotted lines are added to guide the eye and define this space. The SV-OOA and LV-OOA components at multiple sites fall into two distinct regions in this triangle: SV-OOA components are concentrated in the lower half of the triangle, while the LV-OOA components are concentrated in the upper half of the triangle. The total OOA components show an intermediate range of $f_{44}$. Results from Morgan et al. (2010) show that data from aircraft measurements in Europe also lie in the region defined by these guidelines.
The base of the triangular region in Fig. 4 defines the large range in $f_{43}$ that is observed for the less oxidized SV-OOA components. Since the SV-OOA components represent less oxidized and photochemically younger organics, the variability in $f_{43}$ for these components likely arises from differences in OOA components arising from different sources and chemical pathways. The following sites likely have strong influence from biogenic SOA sources: Duke Forest, Hyytiälä, Thompson Farm, Chebogue, and Egbert (Allan et al., 2006; Williams et al., 2007; Cottrell et al., 2008; Raatikainen et al., 2010; Slowik et al., 2010). The SV-OOA components from these sites are marked with an asterisk in Fig. 4. They do not appear to cluster at a certain location inside the triangle, indicating that mass spectral characteristics alone are not enough to assign a particular dominant source (e.g., "anthropogenic" vs. "biogenic") to the OOA components or to different parts of the space in Fig. 4.

In Fig. 4 , both the average and range in $f_{43}$ for OOA components decrease with increasing $f_{44}$. This suggests that the OOA components become more chemically similar with increasing $\mathrm{O}: \mathrm{C}$ and photochemical aging regardless of the original source of the OOA. It is important to note that this ambient trend in OOA composition measured by the AMS is also mirrored in the ambient HULIS sample mass spectra. The HULIS and fulvic acids shown in this study have some of the highest $f_{44}$ values and fall in the LV-OOA range of the figure. Only one of the HULIS samples falls into the $\mathrm{SV}-\mathrm{OOA}$ region; this is the OA collected at Kpustza (Hungary) which likely has a large contribution from freshlyformed biogenic SOA, and also has different optical properties than the biomass burning and pollution HULIS which appear in the LV-OOA region (Dinar et al., 2008). Owing to the very limited amount of the extracted and purified material, an acidity measurement of the HULIS samples analyzed in this work was not performed. However, previous ${ }^{1} \mathrm{H}-\mathrm{NMR}$ studies on HULIS extracted from smoke particles in Brazil showed that their acidic content was as high as 13\% (almost 1 carbon out of 7 of the accounted carbons are carboxylic acids) (Tagliavini et al., 2006), comparable to that reported for fulvic acid samples (Ritchie and Perdue, 2003; Dinar et al., 2006). The highly acidic nature of HULIS and fulvic acids is consistent with the large $f_{44}\left(\mathrm{CO}_{2}^{+}\right)$fragment in their mass spectra. HULIS is found to constitute a large fraction of water soluble organic compounds in ambient aerosols (e.g. Facchini et al., 2000; Decesari et al., 2001; Fuzzi et al., 2001). The $f_{44}$ of LV-OOA is very similar to that for HULIS, which is consistent with the convergence of atmospheric OA to the more oxidized LV-OOA (hence higher acidic content) with aging. This continuum of evolution of OA is also observed in the aircraft data discussed in Morgan et al. (2010).

The OOA components shown in Fig. 4 reflect different locations, sources, and degrees of photochemical aging. Each data point in the figure, in effect, represents a different "snapshot" of atmospheric OA as it is formed and aged in the atmosphere. When taken together, all the points provide a 
broad view of the process by which ambient OA evolves into LV-OOA. In Fig. 4, this evolution is viewed in terms of changes in $f_{44}$ and $f_{43}$. Fig. 5 shows an alternative view of the same evolution in terms of $f_{44}$ and O:C vs. 44/43. For the UMR data, O:C is estimated using the method of Aiken et al. (2008); for the HR data the O:C is directly determined by elemental analysis (Aiken et al., 2007, 2008). Mathematically, a line in the $f_{44}$ vs. $f_{43}$ plot will transform into a curve in the $f_{44}$ vs. $44 / 43$ space (derivation shown in Appendix). Hence, the two dotted lines in Fig. 4 become the two dotted curves in Fig. 5. In Fig. 5, the OOA components from all sites (and time-dependent data at Riverside) also map a curve, showing a transition from SV-OOA components at the lower part of curve to LV-OOA components at the top of the curve with increased photochemical aging. It appears the O:C increases sharply at the beginning of oxidation then plateaus around a value of 1.2, suggesting that this may represent a maximum atmospheric oxidation state of the aerosol.

While Fig. 5 is a mathematically equivalent way of viewing the information in Fig. 4, it can potentially provide a more useful way of connecting the AMS observations with other measurements. In particular, measurements of O:C can be obtained with other instruments such as thermal techniques and nanoaerosol mass spectrometry (Pang et al., 2006; Wang et al., 2006). As discussed before, $\mathrm{m} / \mathrm{z} 44$ in OOA spectra is thought to be due mostly to acidic groups (-COOH) and the $m / z 43$ in OOA spectra can potentially be linked to non-acid oxygenates. Thus, the ratio between these two ions may provide a measure of how the chemical functionality of the OOA evolves with oxidation. Recently, a study by Russell et al. (2009) showed that ratios of AMS fragments (rather than the ratio of individual fragments to total OA) showed some correspondence with the relative abundances of various OA functional groups determined with FTIR. For instance, in regions where $m / z 44$ and $m / z 57$ are both well above the respective detection limits, it was shown that the $44 / 57$ ratio correlates with the ratio of carboxylic acid to alkane functional groups from FTIR (Russell et al., 2009). Comparisons of the FTIR measurements with $44 / 43$ ratios were not reported by Russell et al. (2009). However, future studies involving simultaneous measurements of laboratory standards, or laboratory SOA (from "simple" systems in which both the gas-phase and product-phase chemistry and products are better characterized) with HR-ToF-AMS and FTIR, NMR, or other techniques may provide more detailed insight into how the 44/43 ratio is related to the chemical functionality of OOA. For instance, a HR-ToF-AMS flow reactor study by Kroll et al. (2009) has suggested that $\mathrm{C}_{2} \mathrm{H}_{3} \mathrm{O}^{+}$(nominal mass $=43$ ) and $\mathrm{CO}_{2}^{+}$(nominal mass $=44$ ) may be markers for functionalization reactions and fragmentation reactions, respectively.

\subsection{Comparison with laboratory data}

Over the last two decades, numerous laboratory experiments have been conducted to study the formation of SOA. The results from these experiments form the basis for simulating SOA formation in the atmosphere. In the previous sections, we have provided an overview of the OOA components observed in the ambient atmosphere. In order to allow accurate parameterizations of SOA formation and evolution in the atmosphere, it is desirable that the laboratory conditions be as representative as possible of those in the atmosphere. A careful examination of the similarities and differences between laboratory SOA and ambient OOA provides insights about SOA formation in the atmosphere. A series of laboratory data are compiled from both published and unpublished data (Fig. 6a-c). Figure 6a shows the $f_{44}$ vs. $f_{43}$ for SOA formed by the ozonolysis/photooxidation of a suite of biogenic precursors from chamber experiments, including isoprene, monoterpenes ( $\alpha$-pinene, $\beta$-pinene, $\alpha$ terpinene, terpinolone, limonene, myrcene), oxygenated terpenes (methyl-chavicol, verbenone, linalool), and sesquiterpenes (longifolene, $\alpha$-humulene, $\beta$-caryophyllene). Details on SOA formation in these particular experiments have been discussed in other publications (e.g. Gao et al., 2004a, b; Bahreini et al., 2005; Kroll et al., 2006; Lee et al., 2006a, b; Ng et al., 2006, 2007a; Alfarra et al., 2006; Zhang et al., 2006; Shilling et al., 2009). Figure 6a also includes flow tube data of the heterogeneous oxidation (by OH radicals) of SOA formed from $\alpha$-pinene ozonolysis, denoted by the LBNL data points (Jimenez et al., 2009). Figure $6 \mathrm{~b}$ shows the chamber data from the photooxidation of a series of aromatic hydrocarbons, including $m$-xlyene, toluene, benzene, and 1,3,5trimethylbenzene (Alfarra et al., 2006; Ng et al., 2007b; Hildebrandt et al., 2009). Figure $6 \mathrm{c}$ shows the chamber and flow tube data from the photooxidation/heterogeneous oxidation of POA (and also primary vapors in some cases) (George et al., 2007; Sage et al., 2008; Grieshop et al., 2009; Kroll et al., 2009; Presto et al., 2009; Smith et al., 2009). The LBNL squalane data and CMU n-heptadecane data are HR data (the $m / z 43$ data shown are from the $\mathrm{C}_{2} \mathrm{H}_{3} \mathrm{O}^{+}$fragment) and residual analysis has been performed on the UMR diesel and wood smoke data (Sage et al., 2008; Grieshop et al., 2009), allowing for direct comparison of these datasets with ambient OOA components and chamber SOA.

In Fig. 6a, b, and c, the lines connecting the data points indicate the range of $f_{44}$ and $f_{43}$ observed in each experiment. As explained in more detail below, the range observed does not necessarily correspond to the beginning and end of the experiments. The two dotted lines in these figures are the same as those in Fig. 4, encompassing the space in which the ambient data fall. It is clear that most laboratory data fall into the same region as the ambient data. There are two exceptions: $\alpha$-pinene SOA formed in flow tube experiments (Jimenez et al., 2009), and isoprene SOA formed under low $\mathrm{NO}_{\mathrm{x}}\left(\mathrm{H}_{2} \mathrm{O}_{2}\right.$ photolysis) conditions (Kroll et al., 2006). The 


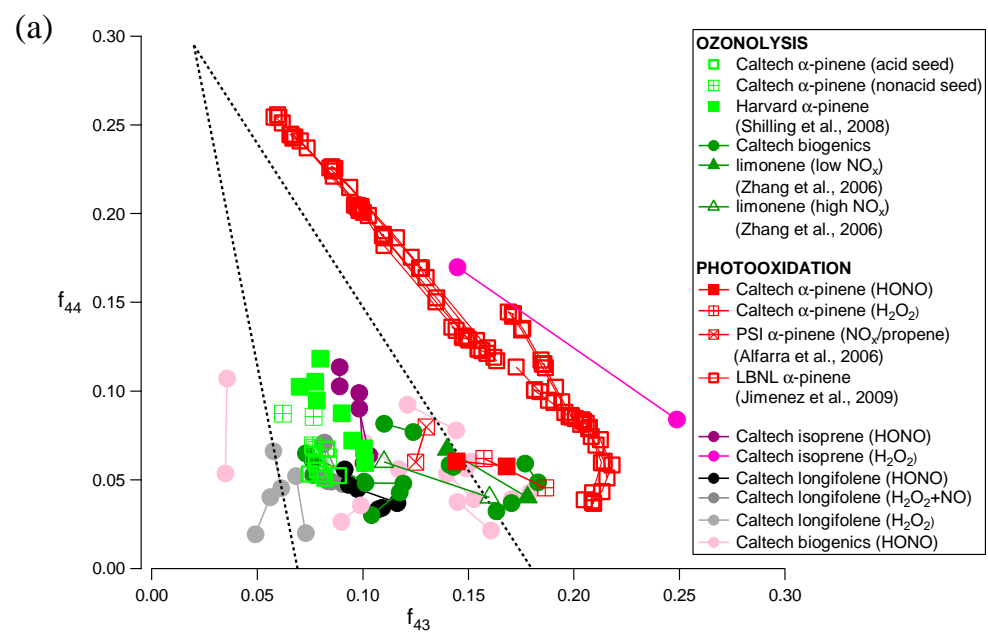

(b)

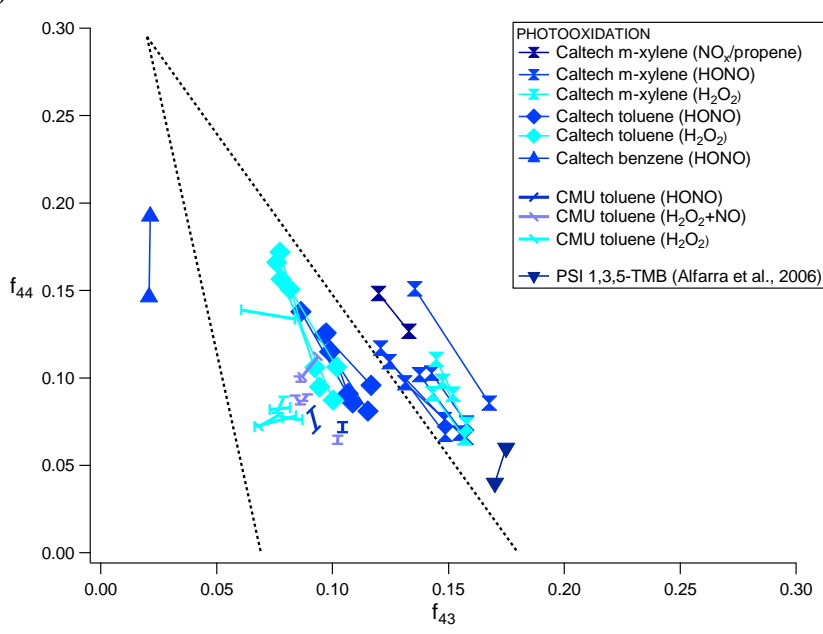

(c)

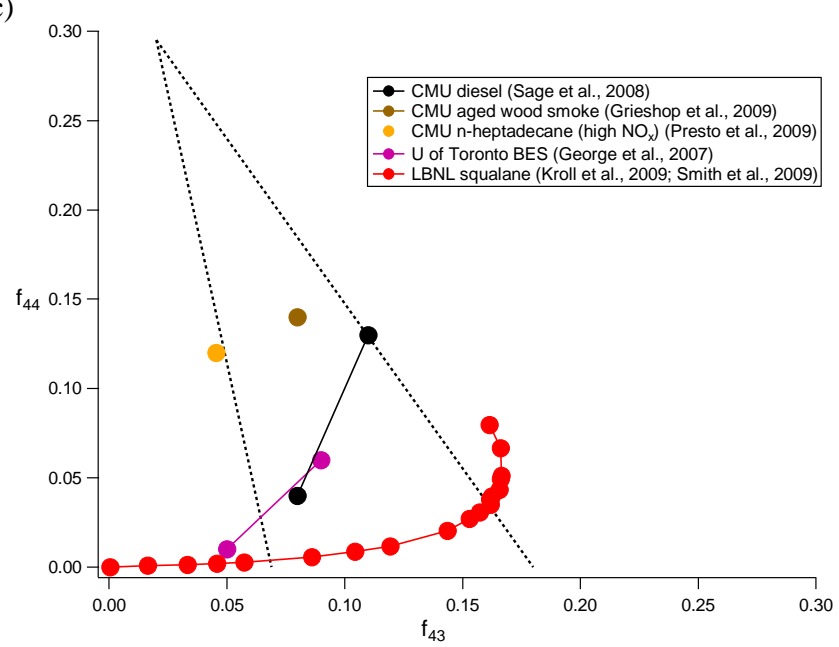

Fig. 6. (a) $f_{44}$ vs. $f_{43}$ for SOA formed by the ozonolysis/photooxidation of a suite of biogenic precursors from chamber experiments, including isoprene, terpenes, and sesquiterpenes (Gao et al., 2004a, b; Bahreini et al., 2005; Kroll et al., 2006; Lee et al., 2006a, b; Ng et al., 2006; $\mathrm{Ng}$ et al., 2007a). Also shown in this figure are flow tube data of the heterogeneous oxidation (by OH radicals) of SOA formed from $\alpha$-pinene ozonolysis (LBNL data). The lines connecting the data points indicate the range of $f_{44}$ and $f_{43}$ observed in each experiment. For $\alpha$-pinene ozonolysis, only the values at the end of the experiment are shown to avoid crowding the plot. The two dotted lines are the same as those in Fig. 4. (b) Chamber data from the photooxidation of a series of aromatic hydrocarbons, including $m$-xlyene, toluene, benzene, and 1,3,5-trimethylbenzene (Ng et al., 2007b; Hildebrandt et al., 2009). The lines connecting the data points indicate the range of $f_{44}$ and $f_{43}$ observed in each experiment. The two dotted lines are the same as those in Fig. 4. (c) Chamber and flow tube data from the photooxidation/heterogeneous oxidation of POA. The LBNL squalane data and CMU n-heptadecane data are HR data (the $m / z 43$ data shown are from the $\mathrm{C}_{2} \mathrm{H}_{3} \mathrm{O}^{+}$fragment). For diesel and wood smoke (Sage et al., 2008; Grieshop et al., 2009), the data shown here are from the residual mass spectra (i.e. spectra in which the POA contribution has been excluded). The LBNL squalane data starts from zero because the experiment starts with HOA. The two dotted lines are the same as those in Fig. 4.

reason for the higher $f_{43}$ observed in the flow tube experiments is unclear at this point. It is possible that the SOA formed in these experiments experiences a higher degree of heterogeneous oxidation owing to the very high $\mathrm{OH}$ levels, which may result in different aerosol compositions compared to the much gentler oxidation in chamber experiments. For the low- $\mathrm{NO}_{\mathrm{x}}$ isoprene SOA, HR data show that other than $\mathrm{CO}_{2}^{+}$, there is substantial contribution of $\mathrm{C}_{2} \mathrm{H}_{4} \mathrm{O}^{+}$at $\mathrm{m} / \mathrm{z}$ 44 for SOA formed from the photooxidation of erythritol
(Kessler et al., 2010), which is structurally very similar to the tetrols observed in isoprene low- $\mathrm{NO}_{\mathrm{x}} \mathrm{SOA}$ (Surratt et al., 2006; Kleindienst et al., 2009). Hence, it is expected that the $\mathrm{m} / z 44$ of the isoprene SOA shown in Fig. 6a will also have substantial contributions from non- $\mathrm{CO}_{2}^{+}$ions, resulting in the relatively higher values compared to other experiments. This issue should be revisited when HR data for most of these reactions become available by plotting $\mathrm{CO}_{2}^{+} / \mathrm{OA}$ instead of $f_{44}$. 


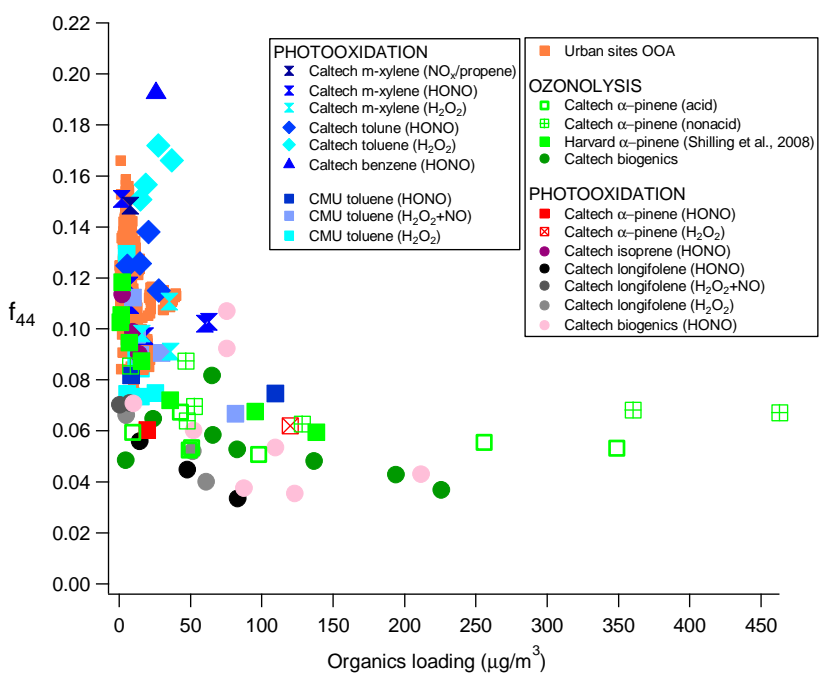

Fig. 7. $f_{44}$ as a function of organics loading (measured with AMS) for the chamber experiments shown in Figs. 6a and b. For each experiment, only the highest $f_{44}$ value is shown to avoid crowding the plot. The orange points are the OOA data from various urban sites (Beijing, Tokyo summer, NYC summer, Riverside, Pittsburgh).

The majority of the laboratory data (Fig. 6a-c) fall into the triangle region in Fig. 4 as well as the curve envelope in Fig. 5. However, most of the data reside in the lower half of the triangle (and lower half of the curve), indicating that the laboratory SOA is more similar to the less oxidized ambient SV-OOA, and rarely become as oxidized as ambient LVOOA. Similar to SV-OOA, there is quite a large variability in the $f_{43}$ in the laboratory data. This is not surprising as the data encompass a wide range of SOA precursors and experimental conditions such as types of oxidants, oxidant concentrations (exposure), initial hydrocarbon concentrations, $\mathrm{NO}_{\mathrm{x}}$ level, temperature, relative humidity, etc. Possible reasons for laboratory SOA being less oxidized than ambient OOA are: higher loadings employed in many laboratory experiments that favor partitioning of less oxidized species (which would remain in the gas phase under atmospheric conditions) (Duplissy et al., 2008; Shilling et al., 2009) and limited residence time in chambers (which limits the degree of aging accessible in chamber experiments). To explore the first possibility, Fig. 7 shows $f_{44}$ as a function of OA concentration for all of the chamber experiments in Fig. 6a and b. For each experiment, only the highest $f_{44}$ value is shown to avoid crowding the plot. Also shown in Fig. 7 are the OOA data from various urban sites (Beijing, Tokyo summer, NYC summer, Riverside, Pittsburgh). These OOA data include only the time periods when variable partitioning of semi-volatiles is expected (i.e. time periods when there is relatively low temperature, and/or changing temperature). The laboratory data with lower loadings overlap the ambient data. When putting all the data together, it is clear that $f_{44}$ decreases with increasing loading. This is consistent with semivolatile par-

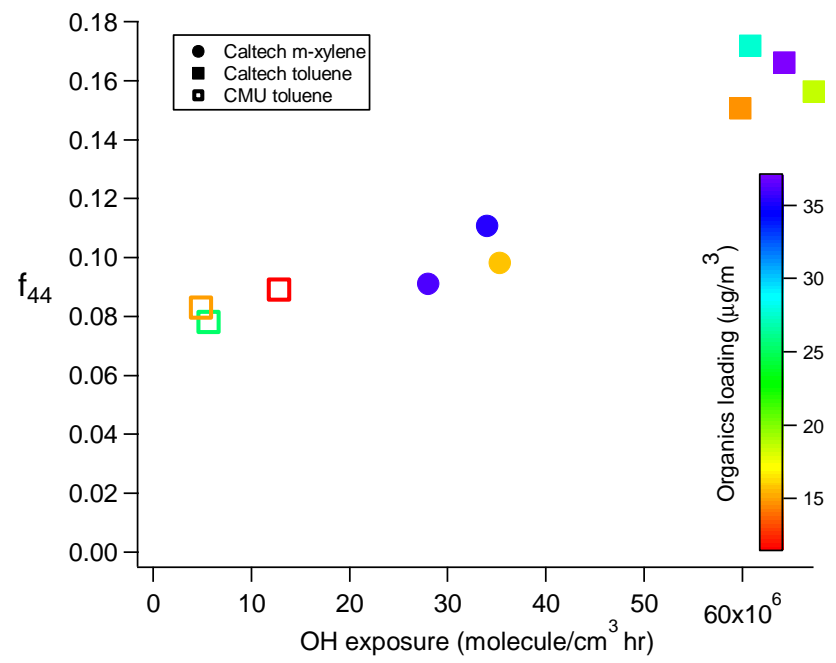

Fig. 8. $f_{44}$ (highest $f_{44}$ observed in the experiment) vs. the $\mathrm{OH}$ exposure for SOA formed from the photooxidation of $m$-xylene and toulene under low- $\mathrm{NO}_{\mathrm{x}}\left(\mathrm{H}_{2} \mathrm{O}_{2}\right)$ conditions ( $\mathrm{Ng}$ et al., 2007b; Hildebrandt et al., 2009). Each data point is colored according to the loading of that particular experiment.

titioning (Odum et al., 1996; Donahue et al., 2006); with increasing OA concentration even the less oxidized and more volatile species will partition into the aerosol phase, resulting in a lower $f_{44}$. The change (decreasing $f_{44}$ with increasing loading) is most dramatic at lower loadings $\left(0-20 \mu \mathrm{g} / \mathrm{m}^{3}\right.$, which are typical in the atmosphere), and it appears to level off for loadings higher than $\sim 100 \mu \mathrm{g} / \mathrm{m}^{3}$. The effect of loading on composition of SOA formed from a particular system ( $\alpha$-pinene ozonolysis) has been investigated in a recent study (Shilling et al., 2009) and the results are consistent with this work.

Again, the main reason for the scatter in Fig. 7 likely arises from the wide range of precursors and experimental conditions. However, comparing experiments carried out under similar conditions underscores the importance of oxidation time and oxidant exposure in laboratory experiments. As seen in Fig. 6b, SOA formed from the photooxidation of aromatics in the smaller Carnegie Mellon chamber is substantially less oxidized than in the larger Caltech chamber. Figure 8 shows the $f_{44}$ (highest $f_{44}$ observed in the experiment) vs. the $\mathrm{OH}$ exposure for low- $\mathrm{NO}_{\mathrm{x}}$ experiments from both datasets; each data point is colored according to the loading of that particular experiment. As seen in Fig. 8, some of the toluene experiments from these two datasets have very similar loadings; however, the $f_{44}$ observed in the Caltech experiments is substantially higher as a result of the increased $\mathrm{OH}$ exposure. The difference in $\mathrm{OH}$ exposure arises mainly from the larger oxidation time afforded by the smaller relative wall losses of the larger Caltech chamber, as the $\mathrm{OH}$ concentrations employed in both datasets are comparable $(\sim 1-$ $3 \times 10^{6}$ molecules $/ \mathrm{cm}^{3}$, estimated from the decay of the hydrocarbon) (Ng et al., 2007b; Hildebrandt et al., 2009). It 
is noted that the flow tube $\alpha$-pinene data (LBNL data) also have extremely high $f_{44}$ values, likely a result of the very high $\mathrm{OH}$ concentrations (up to $8 \times 10^{10}$ molecules $/ \mathrm{cm}^{3}$ ) used in the flow tube experiments (Jimenez et al., 2009), corresponding to very high levels of atmospheric aging. In summary, both the higher organic mass loadings and the limited aging likely explain why the chamber data do not reach the levels of oxidation observed in the atmosphere.

Several interesting observations can be made when examining the laboratory data in more detail. From Fig. 6a, it appears that the SOA formed from $\alpha$-pinene photooxidation has a relatively higher $f_{43}$ than that formed from $\alpha$-pinene ozonolysis. SOA formed from biogenic hydrocarbons spans a similar range in $f_{44}$ in ozonolysis and photooxidation experiments. However, the evolution of $m / z 44$ as a function of OA concentration for these two types of experiments is very different, as shown in Fig. 9a ( $\alpha$-pinene ozonolysis) and Fig. $9 \mathrm{~b}$ ( $\alpha$-pinene photooxidation). In both experiments, $m / z 44$ decreases with increasing OA during the early phrase of the experiment. With the very low loading at the initial stage of SOA growth, only the highly oxygenated and least volatile species will partition into the aerosol phase, resulting in a higher $f_{44}$. However, these highly oxygenated species are later diluted in the particle phase by the partitioning of less-oxygenated semivolatile species with increased OA concentration. Such behavior has been observed in several previous studies (Bahreini et al., 2005; Baltensperger et al., 2005; Zhang et al., 2006; Duplissy et al., 2008; Shilling et al., 2009). After SOA mass peaks, the loadings decrease owing to wall loss. The $f_{44}$ in the ozonolysis experiment stays relatively constant during this period. This is not surprising as ozone reacts only with the double bond, and further chemistry ceases after all $\alpha$-pinene is consumed. When loadings decrease due to wall loss, one might expect that the semivolatile species would partition back to the gas-phase and result in higher $f_{44}$ in the SOA. The lack of this observation suggests that the particles lost to the wall still participate in the partitioning, consistent with previous studies (Weitkamp et al., 2007; Hildebrandt et al., 2009). On the other hand, the $f_{44}$ in the photooxidation experiment continues to increase after peak aerosol growth, indicating further changes in SOA composition with photochemical aging. The increase in $f_{44}$ with decreased loading (due to wall loss) does not trace the original path as the gas-phase chemistry in the chamber is constantly changing. It is noted that similar behavior is also observed in the ozonolysis and photooxidation of other biogenic hydrocarbons. The evolution of $f_{44}$ with organic mass loadings is quite different for aromatic hydrocarbons (e.g. $m$-xylene as shown in Fig. 9c). Unlike $\alpha$-pinene, the $f_{44}$ starts increasing from the beginning of the experiment and continues over the course of the experiment. This suggests that the products formed from the photooxidation of $m$-xylene are generally less volatile, consistent with the higher $f_{44}$ values in aromatic experiments (compared to biogenics experiments). After peak SOA growth, the $f_{44}$ also (a)

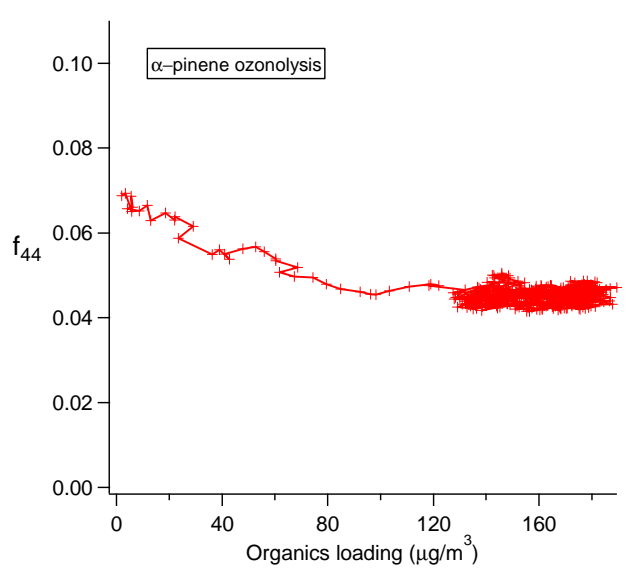

(b)

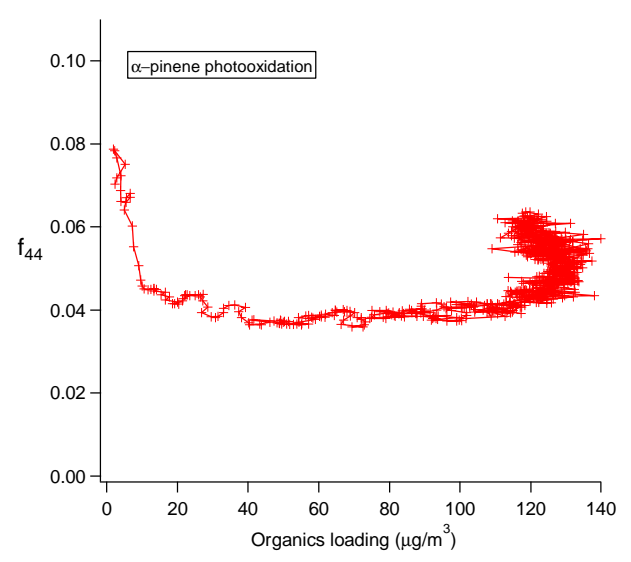

(c)

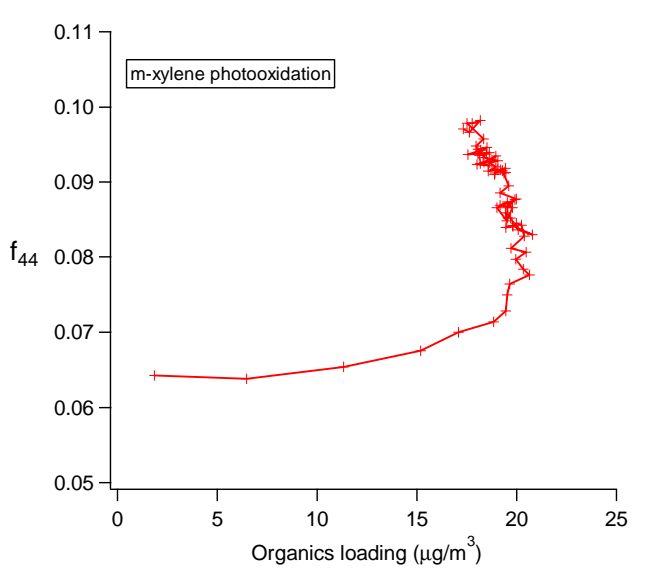

Fig. 9. (a): Change in $f_{44}$ as a function of organics loading over the course of a typical $\alpha$-pinene ozonolysis experiment. (b): Change in $f_{44}$ as a function of organics loading over the course of a typical $\alpha$-pinene photooxidation experiment (low- $\mathrm{NO}_{\mathrm{x}}$ ). (c): Change in $f_{44}$ as a function of organics loading over the course of a typical $m$-xylene photooxidation experiment (low- $\mathrm{NO}_{\mathrm{x}}$ ). 
continues to increase as a result of further oxidation. All these observations highlight the dynamics of SOA evolution. While peak aerosol growth is useful for determining SOA yields in chamber experiments, further chemistry can still be ongoing and should not be overlooked.

\section{Conclusions}

In this study we present results from the factor analysis of 43 AMS datasets (27 of the datasets are reanalyzed in this work) and provide an overview of OOA components in the Northern Hemisphere and their evolution in the atmosphere. At most sites, we are able to resolve the OA into HOA and OOA components. For some sites a BBOA factor is also observed. In many analyses, we can further separate the OOA into LVOOA and SV-OOA components. A wide range of O:C ratio is observed for both LV-OOA $(0.73 \pm 0.14)$ and SV-OOA $(0.35 \pm 0.14)$ components, highlighting the range of conditions that give rise to these factors, such as meteorology, SOA precursors, and photochemical aging. The OOA components (OOA, LV-OOA, and SV-OOA) from all sites cluster within a well-defined triangular region in the $f_{44}$ vs. $f_{43}$ space. These observations allow for a standardized means of comparing and characterizing any OOA components (laboratory or ambient) observed with the AMS. Viewing laboratory data in this space, for example, allows for a direct connection between laboratory and ambient measurements. A compilation of AMS laboratory SOA data reveals that laboratory SOA falls into the lower half of the triangular region, characteristic of lower O:C ratios and photochemical ages. The laboratory SOA is more similar to SV-OOA components and rarely become as oxidized as LV-OOA components. This likely arises from the higher loadings and limited oxidation time in most laboratory experiments.

While the OOA components observed at the different locations differ according to their respective sources, meteorology, and degrees of photochemical aging, when taken together they provide a generalized view of the photochemical aging process of ambient OA. In particular, the oxidation process results in increasingly similar OOA composition regardless of the original OOA source. Moreover, it appears that the transformation between SV-OOA and LV-OOA at multiple sites shares common features that could potentially enable a simplified description of the atmospheric oxidation of OA. For instance, the transformation shows a clear trend in O:C vs. $m / z$ 44/43 ratios. While the data presented in the O:C vs. 44/43 space (Fig. 5) is mathematically the same as $f_{44}$ vs. $f_{43}$ triangular space (Fig. 4 ), this plot potentially allows one to more readily connect AMS observations with those obtained by other instruments. The ability to make such connections is invaluable because the evolution of $\mathrm{OA}$ is a complex and dynamic process and there is no single instrument that can capture all of the important features (Hallquist et al., 2009).
Traditionally, SOA models often employ parameters derived from chamber experiments based on a two product partitioning model (Pankow, 1994; Odum et al., 1996), and more recently, the volatility basis-set approach (Lane et al., 2008; Murphy and Pandis, 2009). While SOA yield parameters derived from chamber experiments have proven to be very useful in providing the basis for SOA simulation in the last ten years or so, a modified representation may be better to capture the dynamic evolution of $\mathrm{OA}$ in the atmosphere. The compact view of photochemical SOA oxidation provided by the SV-OOA and LV-OOA components can form the basis of new SOA modeling frameworks. Recently, a twodimensional volatility basis-set (2D-VBS) modeling framework has been proposed that uses OA volatility and oxidation state (approximated by $\mathrm{O}: \mathrm{C}$ ) as its two basis vectors (Jimenez et al., 2009). The model captures the main features of the evolution of OA in multiple field studies and simulation chambers, showing the transformation from SV-OOA to LV-OOA with increasing photochemical aging in the O:C vs. volatility space. A new framework such as this could form the basis of future modeling approaches, and with additional field measurements, laboratory studies, and inventories one will be able to more accurately predict the formation and evolution of OA in the atmosphere.

\section{Appendix A}

In Fig. 4 , the plot shows $f_{44}$ vs. $f_{43}$. We can re-write $f_{44}$ as $44 / \mathrm{OA}$ and $f_{43}$ as 43/OA.

Considering a line in this space:

$\frac{44}{O A}=m \frac{43}{O A}+c$

where $m=$ slope; $\mathrm{c}=$ intercept.

Divide both sides of Eq. (1) by 43:

$$
\begin{aligned}
& \frac{44}{43 * O A}=\frac{m}{O A}+\frac{c}{43} \\
& \frac{44}{43}=m+\frac{c * O A}{43} \\
& \frac{44}{43}-m=\frac{c * O A}{43} \\
& \frac{1}{\frac{44}{43}-m}=\frac{43}{c * O A} \\
& \frac{43}{O A}=\frac{c}{\frac{44}{43}-m}
\end{aligned}
$$

Substitute this back to Eq. (1):

$$
\begin{aligned}
& \frac{44}{O A}=m \frac{c}{\frac{44}{43}-m}+c \\
& \frac{44}{O A}=\frac{m * c}{\frac{44}{43}-m}+c
\end{aligned}
$$

This is a curve in the 44/OA vs. 44/43 space (Fig. 5). 
Acknowledgements. Aerodyne Research acknowledges the following funding for various field campaigns: ICARTT (NOAA NA05OAR4310102); NEAQS (NOAA AB133R04SE0480, NOAA RA1330-02-SE-015O); MILARGO (DOE DE-FGOZO5ER63982, NSF ATM-0528170). Y. Rudich and J. L. Jimenez acknowledge the financial support of the USA-Israel bi-national science foundation (BSF grant \#2008146). I. M. Ulbrich, K. S. Docherty, P. F. DeCarlo, and J. L. Jimenez are grateful for funding from NOAA NA08OAR4310565, NSF ATM-0919189 and DOE DEFG0208ER64627. Q. Zhang acknowledges the support from the Department of Energy's Atmospheric Science Program (Office of Science, BER), Grant no. DEFG02-08ER64627. The authors would like to acknowledge U. Baltensperger, P. J. Ziemann, and L. M. Russell for helpful discussions. We acknowledge the contributions of the following individuals to recently published datasets included in Lanz et al. (2009): Crete (G. J. Engelhart, C. Mohr, and E. Kostenidou); Grenoble (O. Favez, C. George, and B. D'Anna); Rhine Valley (C. Mohr and S. Weimer). We also thank the many other research groups and individuals who contributed datasets included in this work (individual publications are acknowledged in the Tables S1 and S2 in the supplementary material: http://www.atmos-chem-phys.net/10/4625/2010/ acp-10-4625-2010-supplement.pdf.

Edited by: T. Hoffmann

\section{References}

Aiken, A. C., DeCarlo, P. F., and Jimenez, J. L.: Elemental Analysis of Organic Species with Electron Ionization HighResolution Mass Spectrometry, Anal. Chem., 79, 8350-8358, doi:8310.1021/ac071150w, 2007.

Aiken, A. C., Decarlo, P. F., Kroll, J. H., Worsnop, D. R., Huffman, J. A., Docherty, K. S., Ulbrich, I. M., Mohr, C., Kimmel, J. R., Sueper, D., Sun, Y., Zhang, Q., Trimborn, A., Northway, M., Ziemann, P. J., Canagaratna, M. R., Onasch, T. B., Alfarra, M. R., Prevot, A. S. H., Dommen, J., Duplissy, J., Metzger, A., Baltensperger, U., and Jimenez, J. L.: O/C and OM/OC ratios of primary, secondary, and ambient organic aerosols with high-resolution time-of-flight aerosol mass spectrometry, Environ. Sci. Technol., 42, 4478-4485, 2008.

Aiken, A. C., de Foy, B., Wiedinmyer, C., DeCarlo, P. F., Ulbrich, I. M., Wehrli, M. N., Szidat, S., Prevot, A. S. H., Noda, J., Wacker, L., Volkamer, R., Fortner, E., Wang, J., Laskin, A., Shutthanandan, V., Zheng, J., Zhang, R., Paredes-Miranda, G., Arnott, W. P., Molina, L. T., Sosa, G., Querol, X., and Jimenez, J. L.: Mexico City aerosol analysis during MILAGRO using high resolution aerosol mass spectrometry at the urban supersite (T0) - Part 2: Analysis of the biomass burning contribution and the modern carbon fraction, Atmos. Chem. Phys. Discuss., 9, 25915-25981, doi:10.5194/acpd-9-25915-2009, 2009a.

Aiken, A. C., Salcedo, D., Cubison, M. J., Huffman, J. A., DeCarlo, P. F., Ulbrich, I. M., Docherty, K. S., Sueper, D., Kimmel, J. R., Worsnop, D. R., Trimborn, A., Northway, M., Stone, E. A., Schauer, J. J., Volkamer, R. M., Fortner, E., de Foy, B., Wang, J., Laskin, A., Shutthanandan, V., Zheng, J., Zhang, R., Gaffney, J., Marley, N. A., Paredes-Miranda, G., Arnott, W. P., Molina, L. T., Sosa, G., and Jimenez, J. L.: Mexico City aerosol analysis during MILAGRO using high resolution aerosol mass spectrom- etry at the urban supersite (T0) - Part 1: Fine particle composition and organic source apportionment, Atmos. Chem. Phys., 9, 6633-6653, doi:10.5194/acp-9-6633-2009, 2009b.

Alfarra, M. R.: Insights into the atmospheric organic aerosols using an aerosol mass spectrometer, Thesis, University of Manchester, UK, 2004.

Alfarra, M. R., Coe, H., Allan, J. D., Bower, K. N., Boudries, H., Canagaratna, M. R., Jimenez, J. L., Jayne, J. T., Garforth, A. A., Li, S. M., and Worsnop, D. R.: Characterization of urban and rural organic particulate in the lower Fraser valley using two Aerodyne aerosol mass spectrometers, Atmos. Environ., 38, 57455758, 2004.

Alfarra, M. R., Paulsen, D., Gysel, M., Garforth, A. A., Dommen, J., and Prévôt, A. S. H., Worsnop, D. R., Baltensperger, U., and Coe, H.: A mass spectrometric study of secondary organic aerosols formed from the photooxidation of anthropogenic and biogenic precursors in a reaction chamber, Atmos. Chem. Phys., 6, 5279-5293, 2006, http://www.atmos-chem-phys.net/6/5279/2006/.

Allan, J. D., Alfarra, M. R., Bower, K. N., Coe, H., Jayne, J. T., Worsnop, D. R., Aalto, P. P., Kulmala, M., Hyotylainen, T., Cavalli, F., and Laaksonen, A.: Size and composition measurements of background aerosol and new particle growth in a Finnish forest during QUEST 2 using an Aerodyne Aerosol Mass Spectrometer, Atmos. Chem. Phys., 6, 315-327, 2006, http://www.atmos-chem-phys.net/6/315/2006/.

Bahreini, R., Keywood, M. D., Ng, N. L., Varutbangkul, V., Gao, S., Flagan, R. C., Seinfeld, J. H., Worsnop, D. R., and Jimenez, J. L.: Measurements of secondary organic aerosol from oxidation of cycloalkenes, terpenes, and $m$-xylene using an Aerodyne aerosol mass spectrometer, Environ. Sci. Technol., 39, 5674-5688, 2005.

Baltensperger, U., Kalberer, M., Dommen, J., Paulsen, D., Alfarra, M. R., Coe, H., Fisseha, R., Gascho, A., Gysel, M., Nyeki, S., Sax, M., Steinbacher, M., Prévôt, A. S. H., Sjogren, S., Weingartner, E., and Zenobi, R.: Secondary organic aerosols from anthropogenic and biogenic precursors, Faraday Discussions, 130, 265-278, 2005.

Canagaratna, M. R., Jayne, J. T., Jimenez, J. L., Allan, J. D., Alfarra, M. R., Zhang, Q., Onasch, T. B., Drewnick, F., Coe, H., Middlebrook, A., Delia, A., Williams, L. R., Trimborn, A. M., Northway, M. J., DeCarlo, P. F., Kolb, C. E., Davidovits, P., and Worsnop, D. R.: Chemical and microphysical characterization of ambient aerosols with the Aerodyne aerosol mass spectrometer, Mass Spectrom. Rev., 26, 185-222, 2007.

Cappa, C. D., Bates, T. S., Quinn, P. K., and Lack, D. A.: Source characterization from ambient measurements of aerosol optical properties, Geophys. Res. Lett., 36, L14813, doi:10.1029/2009GL038979, 2009.

Cottrell, L. D., Griffin, R. J., Jimenez, J. L., Zhang, Q., Ulbrich, I., Ziemba, L. D., Beckman, P. J., Sive, B. C., and Talbot, R. W.: Submicron particles at Thompson Farm during ICARTT measured using aerosol mass spectrometry, J. Geophys. Res.-Atmos., 113, D08212, doi:10.1029/2007JD009192, 2008.

de Gouw, J. A., Middlebrook, A. M., Warneke, C., Goldan, P. D., Kuster, W. C., Roberts, J. M., Fehsenfeld, F. C., Worsnop, D. R., Canagaratna, M. R., Pszenny, A. A. P., Keene, W. C., Marchewka, M., Bertman, S. B., and Bates, T. S.: Budget of organic carbon in a polluted atmosphere: Results from the New England Air Quality Study in 2002, J. Geophys. Res.-Atmos., 
110, D16305, doi:16310.11029/12004JD005623, 2005.

DeCarlo, P. F., Kimmel, J. R., Trimborn, A., Northway, M. J., Jayne, J. T., Aiken, A. C., Gonin, M., Fuhrer, K., Horvath, T., Docherty, K., Worsnop, D. R., and Jiménez, J. L.: A FieldDeployable High-Resolution Time-of-Flight Aerosol Mass Spectrometer, Anal. Chem., 78, 8281-8289, 2006.

Decesari, S., Facchini, M. C., Matta, E., Lettini, F., Mircea, M., Fuzzi, S., Tagliavini, E., and Putaud, J. P.: Chemical features and seasonal variation of fine aerosol water-soluble organic compounds in the Po Valley, Italy, Atmos. Environ., 35, 3691-3699, 2001.

Dinar, E., Taraniuk, I., Graber, E. R., Katsman, S., Moise, T., Anttila, T., Mentel, T. F., and Rudich, Y.: Cloud Condensation Nuclei properties of model and atmospheric HULIS, Atmos. Chem. Phys., 6, 2465-2481, 2006,

http://www.atmos-chem-phys.net/6/2465/2006/.

Dinar, E., Abo Riziq, A., Spindler, C., Erlick, C., Kissc, G., and Rudich, Y.: The complex refractive index of atmospheric and model humic-like substances (HULIS) retrieved by a cavity ring down aerosol spectrometer, Faraday Discussions, 137, 279-295, 2008.

Docherty, K. S., Stone, E. A., Ulbrich, I. M., DeCarlo, P. F., Snyder, D. C., Schauer, J. J., Peltier, R. E., Weber, R. J., Murphy, S. M., Seinfeld, J. H., Grover, B. D., Eatough, D. J., and Jiimenez, J. L.: Apportionment of Primary and Secondary Organic Aerosols in Southern California during the 2005 Study of Organic Aerosols in Riverside (SOAR-1), Environ. Sci. Technol., 42, 7655-7662, 2008.

Donahue, N. M., Robinson, A. L., Stanier, C. O., and Pandis, S. N.: Coupled partitioning, dilution, and chemical aging of semivolatile organics, Environ. Sci. Technol., 40, 2635-2643, 2006.

Drewnick, F., Hings, S. S., DeCarlo, P., Jayne, J. T., Gonin, M., Fuhrer, K., Weimer, S., Jimenez, J. L., Demerjian, K. L., Borrmann, S., and Worsnop, D. R.: A new time-of-flight aerosol mass spectrometer (TOF-AMS) - Instrument description and first field deployment, Aerosol Sci. Technol., 39, 637-658, 2005.

Duplissy, J., Gysel, M., Alfarra, M. R., Dommen, J., Metzger, A., Prevot, A. S. H., Weingartner, E., Laaksonen, A., Raatikainen, T., Good, N., Turner, S. F., McFiggans, G., and Baltensperger, U.: Cloud forming potential of secondary organic aerosol under near atmospheric conditions, Geophys. Res. Lett., L03818, doi:10.1029/2007GL031075, 2008.

Facchini, M. C., Decesari, S., Mircea, M., Fuzzi, S., and Loglio, G.: Surface tension of atmospheric wet aerosol and cloud/fog droplets in relation to their organic carbon content and chemical composition, Atmos. Environ., 34, 4853-4857, 2000.

Faulhaber, A. E., Thomas, B. M., Jiménez, J. L., Jayne, J. T., Worsnop, D. R., and Ziemann, P. J.: Characterization of a thermodenuder- particle beam mass spectrometer system for the study of organic aerosol volatility and composition, Atmos. Meas. Tech., 1, 15-31, 2009,

http://www.atmos-meas-tech.net/1/15/2009/.

Fuzzi, S., Decesari, S., Facchini, M. C., Matta, E., Mircea, M., and Tagliavini, E.: A simplified model of the water soluble organic component of atmospheric aerosols, Geophys. Res. Lett., 28, 4079-4082, 2001.

Gao, S., Keywood, M., Ng, N. L., Surratt, J., Varutbangkul, V., Bahreini, R., Flagan, R. C., and Seinfeld, J. H.: Low-molecular- weight and oligomeric components in secondary organic aerosol from the ozonolysis of cycloalkenes and $\alpha$-pinene, J. Phys. Chem. A, 108, 10147-10164, 2004a.

Gao, S., Ng, N. L., Keywood, M., Varutbangkul, V., Bahreini, R., Nenes, A., He, J. W., Yoo, K. Y., Beauchamp, J. L., Hodyss, R. P., Flagan, R. C., and Seinfeld, J. H.: Particle phase acidity and oligomer formation in secondary organic aerosol, Environ. Sci. Technol., 38, 6582-6589, 2004b.

George, I. J., Vlasenko, A., Slowik, J. G., Broekhuizen, K., and Abbatt, J. P. D.: Heterogeneous oxidation of saturated organic aerosols by hydroxyl radicals: uptake kinetics, condensed-phase products, and particle size change, Atmos. Chem. Phys., 7, 4187-4201, 2007,

http://www.atmos-chem-phys.net/7/4187/2007/.

Graber, E. R. and Rudich, Y.: Atmospheric HULIS: How humiclike are they? A comprehensive and critical review, Atmos. Chem. Phys., 6, 729-753, 2006,

http://www.atmos-chem-phys.net/6/729/2006/.

Grieshop, A. P., Donahue, N. M., and Robinson, A. L.: Laboratory investigations of photochemical oxidation of organic aerosol from wood fires - Part 2: Analysis of aerosol mass spectrometer data, Atmos. Chem. Phys., 9, 2227-2240, 2009,

http://www.atmos-chem-phys.net/9/2227/2009/.

Hallquist, M., Wenger, J. C., Baltensperger, U., Rudich, Y., Simpson, D., Claeys, M., Dommen, J., Donahue, N. M., George, C., Goldstein, A. H., Hamilton, J. F., Herrmann, H., Hoffmann, T., Iinuma, Y., Jang, M., Jenkin, M. E., Jimenez, J. L., KiendlerScharr, A., Maenhaut, W., McFiggans, G., Mentel, T. F., Monod, A., Prevot, A. S. H., Seinfeld, J. H., Surratt, J. D., Szmigielski, R., and Wildt, J.: The formation, properties and impact of secondary organic aerosol: current and emerging issues, Atmos. Chem. Phys., 9, 5155-5236, 2009,

http://www.atmos-chem-phys.net/9/5155/2009/.

Herndon, S. C., Onasch, T. B., Wood, E. C., Kroll, J. H., Canagaratna, M. R., Jayne, J. T., Zavala, M. A., Knighton, W. B., Mazzoleni, C., Dubey, M. K., Ulbrich, I. M., Jimenez, J. L., Seila, R., de Gouw, J. A., de Foy, B., Fast, J., Molina, L. T., Kolb, C. E., and Worsnop, D. R.: Correlation of secondary organic aerosol with odd oxygen in Mexico City, Geophys. Res. Lett., , L15804, doi:10.1029/2008GL034058, 2008.

Hildebrandt, L., Donahue, N. M., and Pandis, S. N.: High formation of secondary organic aerosol from the photooxidation of toluene, Atmos. Chem. Phys., 9, 2973-2986, 2009,

http://www.atmos-chem-phys.net/9/2973/2009/.

Hildebrandt, L., Engelhart, G. J., Mohr, C., Kostenidou, E., Lanz, V. A., Bougiatioti, A., DeCarlo, P. F., Prevot, A. S. H., Baltensperger, U., Mihalopoulos, N., Donahue, N. M., and Pandis, S. N.: Aged organic aerosol in the Eastern Mediterranean: the Finokalia Aerosol Measurement Experiment 2008, Atmos. Chem. Phys., 10, 4167-4186, doi:10.5194/acp-10-4167-2010, 2010.

Holzinger, R., Millet, D. B., Williams, B., Lee, A., Kreisberg, N., Hering, S. V., Jimenez, J., Allan, J. D., Worsnop, D. R., and Goldstein, A. H.: Emission, oxidation, and secondary organic aerosol formation of volatile organic compounds as observed at Chebogue Point, Nova Scotia, J. Geophys. Res.-Atmos., 112, D10S24, doi:10.1029/2006JD007599, 2007.

Huffman, J. A., Docherty, K. S., Aiken, A. C., Cubison, M. J., Ulbrich, I. M., DeCarlo, P. F., Sueper, D., Jayne, J. T., Worsnop, D. R., Ziemann, P. J., and Jimenez, J. L.: Chemically-resolved 
aerosol volatility measurements from two megacity field studies, Atmos. Chem. Phys., 9, 7161-7182, doi:10.5194/acp-9-71612009, 2009.

Jayne, J. T., Leard, D. C., Zhang, X. F., Davidovits, P., Smith, K. A., Kolb, C. E., and Worsnop, D. R.: Development of an aerosol mass spectrometer for size and composition analysis of submicron particles, Aerosol Sci. Technol., 33, 49-70, 2000.

Jimenez, J. L., Canagaratna, M. R., and Donahue, N. M., et al.: Evolution of Organic Aerosols in the Atmosphere, Science, 326, 1525-1529, doi:10.1126/science.1180353, 2009.

Kanakidou, M., Seinfeld, J. H., Pandis, S. N., Barnes, I., Dentener, F. J., Facchini, M. C., Van Dingenen, R., Ervens, B., Nenes, A., Nielsen, C. J., Swietlicki, E., Putaud, J. P., Balkanski, Y., Fuzzi, S., Horth, J., Moortgat, G. K., Winterhalter, R., Myhre, C. E. L., Tsigaridis, K., Vignati, E., Stephanou, E. G., and Wilson, J.: Organic aerosol and global climate modelling: a review, Atmos. Chem. Phys., 5, 1053-1123, 2005, http://www.atmos-chem-phys.net/5/1053/2005/.

Kessler, S. H., Smith, J. D., Che, D. L., Wilson, K. R., and Kroll, J. H.: Products of the heterogeneous oxidation of polyhydroxylated organic aerosol species, in preparation, 2010.

Kleindienst, T. E., Lewandowski, M., Offenberg, J. H., Jaoui, M., and Edney, E. O.: The formation of secondary organic aerosol from the isoprene plus $\mathrm{OH}$ reaction in the absence of NOx, Atmos. Chem. Phys., 9, 6541-6558, 2009,

http://www.atmos-chem-phys.net/9/6541/2009/.

Kleinman, L. I., Springston, S. R., Daum, P. H., Lee, Y. N., Nunnermacker, L. J., Senum, G. I., Wang, J., Weinstein-Lloyd, J., Alexander, M. L., Hubbe, J., Ortega, J., Canagaratna, M. R., and Jayne, J.: The time evolution of aerosol composition over the Mexico City plateau, Atmos. Chem. Phys., 8, 1559-1575, 2008, http://www.atmos-chem-phys.net/8/1559/2008/.

Kroll, J. H., Ng, N. L., Murphy, S. M., Flagan, R. C., and Seinfeld, J. H.: Secondary organic aerosol formation from isoprene photooxidation, Environ. Sci. Technol., 40, 1869-1877, 2006.

Kroll, J. H., and Seinfeld, J. H.: Chemistry of secondary organic aerosol: Formation and evolution of low-volatility organics in the atmosphere, Atmos. Environ., 42, 3593-3624, 2008.

Kroll, J. H., Smith, J. D., Che, D. L., Kessler, S. H., Worsnop, D. R., and Wilson, K. R.: Measurement of fragmentation and functionalization pathways in the heterogeneous oxidation of oxidized organic aerosol, Phys. Chem. Chem. Phys., 11, 8005-8014, 2009.

Lane, T. E., Donahue, N. M., and Pandis, S. N.: Simulating secondary organic aerosol formation using the volatility basis-set approach in a chemical transport model, Atmos. Environ., 42, 7439-7451, 2008.

Lanz, V. A., Alfarra, M. R., Baltensperger, U., Buchmann, B., Hueglin, C., and Prévôt, A. S. H.: Source apportionment of submicron organic aerosols at an urban site by factor analytical modelling of aerosol mass spectra, Atmos. Chem. Phys., 7, 15031522, 2007,

http://www.atmos-chem-phys.net/7/1503/2007/.

Lanz, V. A., Alfarra, M. R., Baltensperger, U., Buchmann, B., Hueglin, C., Szidat, S., Wehrli, M. N., Wacker, L., Weimer, S., Caseiro, A., Puxbaum, H., and Prévôt, A. S. H.: Source attribution of submicron organic aerosols during wintertime inversions by advanced factor analysis of aerosol mass spectra, Environ. Sci. Technol., 42, 214-220, 2008.

Lanz, V. A., Prévôt, A. S. H., Alfarra, M. R., Mohr, C., De-
Carlo, P. F., Weimer, S., Gianini, M. F. D., Hueglin, C., Schneider, J., Favez, O., D’Anna, B., George, C., and Baltensperger, U.: Characterization of aerosol chemical composition by aerosol mass spectrometry in Central Europe: an overview, Atmos. Chem. Phys. Discuss., 9, 24985-25021, doi:10.5194/acpd-924985-2009, 2009.

Lee, A., Goldstein, A. H., Keywood, M. D., Gao, S., Varutbangkul, V., Bahreini, R., Ng, N. L., Flagan, R. C., and Seinfeld, J. H.: Gas-phase products and secondary aerosol yields from the ozonolysis of ten different terpenes, J. Geophys. Res.-Atmos., 111, D07302, doi:07310.01029/02005JD006437, 2006a.

Lee, A., Goldstein, A. H., Kroll, J. H., Ng, N. L., Varutbangkul, V., Flagan, R. C., and Seinfeld, J. H.: Gas-phase products and secondary aerosol yields from the photooxidation of 16 different terpenes, J. Geophys. Res.-Atmos., 111, D17305, doi:17310.11029/12006JD00705, 2006b.

Marcolli, C., Canagaratna, M. R., Worsnop, D. R., Bahreini, R., de Gouw, J. A., Warneke, C., Goldan, P. D., Kuster, W. C., Williams, E. J., Lerner, B. M., Roberts, J. M., Meagher, J. F., Fehsenfeld, F. C., Marchewka, M., Bertman, S. B., and Middlebrook, A. M.: Cluster analysis of the organic peaks in bulk mass spectra obtained during the 2002 New England air quality study with an Aerodyne aerosol mass spectrometer, Atmos. Chem. Phys., 6, 5649-5666, 2006, http://www.atmos-chem-phys.net/6/5649/2006/.

McLafferty, L. W. and Turecek, F.: Interpretation of Mass Spectra, University Science Books, Sausalito, California, USA, 1993.

Millet, D. B., Donahue, N. M., Pandis, S. N., Polidori, A., Stanier, C. O., Turpin, B. J., and Goldstein, A. H.: Atmospheric volatile organic compound measurements during the Pittsburgh Air Quality Study: Results, interpretation, and quantification of primary and secondary contributions, J. Geophys. Res.-Atmos., 110, D07S07, doi:10.1029/2004JD004601, 2005.

Morgan, W. T., Allan, J. D., Bower, K. N., Highwood, E. J., Liu, D., McMeeking, G. R., Northway, M. J., Williams, P. I., Krejci, R., and Coe, H.: Airborne measurements of the spatial distribution of aerosol chemical composition across Europe and evolution of the organic fraction, Atmos. Chem. Phys., 10, 4065-4083, doi:10.5194/acp-10-4065-2010, 2010.

Murphy, B. N. and Pandis, S. N.: Simulating the Formation of Semivolatile Primary and Secondary Organic Aerosol in a Regional Chemical Transport Model, Environ. Sci. Technol., 43, 4722-4728, 2009.

Nemitz, E., Jimenez, J. L., Huffman, J. A., Ulbrich, I. M., Canagaratna, M. R., Worsnop, D. R., and Guenther, A. B.: An eddycovariance system for the measurement of surface/atmosphere exchange fluxes of submicron aerosol chemical species - First application above an urban area, Aerosol Sci. Technol., 42, 636657, 2008

Ng, N. L., Kroll, J. H., Keywood, M. D., Bahreini, R., Varutbangkul, V., Flagan, R. C., Seinfeld, J. H., Lee, A., and Goldstein, A. H.: Contribution of first- versus second-generation products to secondary organic aerosols formed in the oxidation of biogenic hydrocarbons, Environ. Sci. Technol., 40, 2283-2297, 2006.

Ng, N. L., Chhabra, P. S., Chan, A. W. H., Surratt, J. D., Kroll, J. H., Kwan, A. J., McCabe, D. C., Wennberg, P. O., Sorooshian, A., Murphy, S. M., Dalleska, N. F., Flagan, R. C., and Seinfeld, J. H.: Effect of $\mathrm{NO}_{\mathrm{x}}$ level on secondary organic aerosol (SOA) 
formation from the photooxidation of terpenes, Atmos. Chem. Phys., 7, 5159-5174, 2007a,

http://www.atmos-chem-phys.net/7/5159/2007/.

Ng, N. L., Kroll, J. H., Chan, A. W. H., Chhabra, P. S., Flagan, R. C., and Seinfeld, J. H.: Secondary organic aerosol formation from $m$-xylene, toluene, and benzene, Atmos. Chem. Phys., 7, 3909-3922, 2007b,

http://www.atmos-chem-phys.net/7/3909/2007/.

Odum, J. R., Hoffmann, T., Bowman, F., Collins, D., Flagan, R. C., and Seinfeld, J. H.: Gas/particle partitioning and secondary organic aerosol yields, Environ. Sci. Technol., 30, 2580-2585, 1996.

Paatero, P. and Tapper, U.: Positive Matrix Factorization - a Nonnegative Factor Model with Optimal Utilization of ErrorEstimates of Data Values, Environmetrics, 5, 111-126, 1994.

Paatero, P.: A weighted non-negative least squares algorithm for three-way 'PARAFAC' factor analysis, Chemometrics Intell. Lab. Syst., 38, 223-242, 1997.

Paatero, P.: The multilinear engine - A table-driven, least squares program for solving multilinear problems, including the n-way parallel factor analysis model, J. Comput. Graph. Stat., 8, 854888,1999

Paatero, P.: Interactive comment on "Interpretation of organic components from positive matrix factorization of aerosol mass spectrometric data" by I. M. Ulbrich et al., Atmospheric Chemistry and Physics Discussions, 8, S2059-S2068, 2008.

Pang, Y., Turpin, B. J., and Gundel, L. A.: On the importance of organic oxygen for understanding organic aerosol particles, Aerosol Sci. Technol., 40, 128-133, 2006.

Pankow, J. F.: An absorption-model of gas-particle partitioning of organic componds in the atmosphere, Atmos. Environ., 28, 185188,1994

Presto, A. A., Miracolo, M. A., Donahue, N. M., Robinson, A. L., Kroll, J. H., and Worsnop, D. R.: Intermediate-Volatility Organic Compounds: A Potential Source of Ambient Oxidized Organic Aerosol, Environ. Sci. Technol., 43, 4744-4749, 2009.

Raatikainen, T., Vaattovaara, P., Tiitta, P., Miettinen, P., Rautiainen, J., Ehn, M., Kulmala, M., Laaksonen, A., and Worsnop, D. R.: Physicochemical properties and origin of organic groups detected in boreal forest using an aerosol mass spectrometer, Atmos. Chem. Phys., 10, 2063-2077, doi:10.5194/acp-10-20632010, 2010.

Ritchie, J. D. and Perdue, E. M.: Proton-binding study of standard and reference fulvic acids, humic acids, and natural organic matter, Geochim. Cosmochim. Acta, 67, 85-96, 2003.

Roberts, J. D. and Caserio, M. C.: Basic Principles of Organic Chemistry, Benjamin, New York, USA, 1964.

Russell, L. M., Bahadur, R., Hawkins, L. N., Allan, J. D., Baumgardner, D., Quinn, P. K., and Bates, T. S.: Organic aerosol characterization by complementary measurements of chemical bonds and molecular fragments, Environ., 43, 6100-6105, 2009.

Sage, A. M., Weitkamp, E. A., Robinson, A. L., and Donahue, N. M.: Evolving mass spectra of the oxidized component of organic aerosol: results from aerosol mass spectrometer analyses of aged diesel emissions, Atmos. Chem. Phys., 8, 1139-1152, 2008, http://www.atmos-chem-phys.net/8/1139/2008/.

Shilling, J. E., Chen, Q., King, S. M., Rosenoern, T., Kroll, J. H., Worsnop, D. R., DeCarlo, P. F., Aiken, A. C., Sueper, D., Jimenez, J. L., and Martin, S. T.: Loading-dependent elemen- tal composition of alpha-pinene SOA particles, Atmos. Chem. Phys., 9, 771-782, 2009,

http://www.atmos-chem-phys.net/9/771/2009/.

Slowik, J. G., Stroud, C., Bottenheim, J. W., Brickell, P. C., Chang, R. Y.-W., Liggio, J., Makar, P. A., Martin, R. V., Moran, M. D., Shantz, N. C., Sjostedt, S. J., van Donkelaar, A., Vlasenko, A., Wiebe, H. A., Xia, A. G., Zhang, J., Leaitch, W. R., and Abbatt, J. P. D.: Characterization of a large biogenic secondary organic aerosol event from eastern Canadian forests, Atmos. Chem. Phys., 10, 2825-2845, doi:10.5194/acp-10-2825-2010, 2010.

Smith, J. D., Kroll, J. H., Cappa, C. D., Che, D. L., Liu, C. L., Ahmed, M., Leone, S. R., Worsnop, D. R., and Wilson, K. R.: The heterogeneous reaction of hydroxyl radicals with submicron squalane particles: a model system for understanding the oxidative aging of ambient aerosols, Atmos. Chem. Phys., 9, 3209-3222, 2009,

http://www.atmos-chem-phys.net/9/3209/2009/.

Sun, J., Zhang, Q., Canagaratna, M. R., Zhang, Y., Ng, N. L., Sun, Y., Jayne, J. T., Zhang, X., Zhang, X., and Worsnop, D. R.: Highly Time- and Size-Resolved Characterization of Submicron Aerosol Particles in Beijing Using an Aerodyne Aerosol Mass Spectrometer, Atmos. Environ., 44, 131-140, 2009.

Surratt, J. D., Murphy, S. M., Kroll, J. H., Ng, N. L., Hildebrandt, L., Sorooshian, A., Szmigielski, R., Vermeylen, R., Maenhaut, W., Claeys, M., Flagan, R. C., and Seinfeld, J. H.: Chemical composition of secondary organic aerosol formed from the photooxidation of isoprene, J. Phys. Chem. A, 110, 9665-9690, 2006.

Tagliavini, E., Moretti, F., Decesari, S., Facchini, M. C., Fuzzi, S., and Maenhaut, W.: Functional group analysis by HNMR/chemical derivatization for the characterization of organic aerosol from the SMOCC field campaign, Atmos. Chem. Phys., 6, 1003-1019, 2006,

http://www.atmos-chem-phys.net/6/1003/2006/.

Takegawa, N., Miyakawa, T., Kawamura, K., and Kondo, Y.: Contribution of selected dicarboxylic and omega-oxocarboxylic acids in ambient aerosol to the $\mathrm{m} / \mathrm{z} 44$ signal of an Aerodyne aerosol mass spectrometer, Aerosol Sci. Technol., 41, 418-437, 2007.

Ulbrich, I. M., Canagaratna, M. R., Zhang, Q., Worsnop, D. R., and Jimenez, J. L.: Interpretation of organic components from Positive Matrix Factorization of aerosol mass spectrometric data, Atmos. Chem. Phys., 9, 2891-2918, 2009, http://www.atmos-chem-phys.net/9/2891/2009/.

Volkamer, R., Jimenez, J. L., San Martini, F., Dzepina, K., Zhang, Q., Salcedo, D., Molina, L. T., Worsnop, D. R., and Molina, M. J.: Secondary organic aerosol formation from anthropogenic air pollution: Rapid and higher than expected, Geophys. Res. Lett., 33, L17811, doi:17810.11029/12006GL026899, 2006.

Wang, S. Y., Zordan, C. A., and Johnston, M. V.: Chemical characterization of individual, airborne sub-10-nm particles and molecules, Anal. Chem., 78, 1750-1754, 2006.

Weitkamp, E. A., Sage, A. M., Pierce, J. R., Donahue, N. M., and Robinson, A. L.: Organic aerosol formation from photochemical oxidation of diesel exhaust in a smog chamber, Environ. Sci. Technol., 41, 6969-6975, 2007.

Williams, B. J., Goldstein, A. H., Millet, D. B., Holzinger, R., Kreisberg, N. M., Hering, S. V., White, A. B., Worsnop, D. R., Allan, J. D., and Jimenez, J. L.: Chemical speciation of 
organic aerosol during the International Consortium for Atmospheric Research on Transport and Transformation 2004: Results from in situ measurements, J. Geophys. Res.-Atmos., 112, D10S26, doi:10.1029/2006JD007601, 2007.

Zhang, J., Hartz, K. E. H., Pandis, S. N., and Donahue, N. M.: Secondary organic aerosol formation from limonene ozonolysis: Homogeneous and heterogeneous influences as a function of $\mathrm{NO}_{\mathrm{x}}$, J. Phys. Chem. A, 110, 11053-11063, 2006.

Zhang, Q., Alfarra, M. R., Worsnop, D. R., Allan, J. D., Coe, H., Canagaratna, M. R., and Jimenez, J. L.: Deconvolution and quantification of hydrocarbon-like and oxygenated organic aerosols based on aerosol mass spectrometry, Environ. Sci. Technol., 39, 4938-4952, 2005a.

Zhang, Q., Worsnop, D. R., Canagaratna, M. R., and Jimenez, J. L.: Hydrocarbon-like and oxygenated organic aerosols in Pittsburgh: insights into sources and processes of organic aerosols, Atmos. Chem. Phys., 5, 3289-3311, 2005b,

http://www.atmos-chem-phys.net/5/3289/2005/.
Zhang, Q., Jimenez, J. L., Canagaratna, M. R., Allan, J. D., Coe, H., Ulbrich, I., Alfarra, M. R., Takami, A., Middlebrook, A. M., Sun, Y. L., Dzepina, K., Dunlea, E., Docherty, K., DeCarlo, P. F., Salcedo, D., Onasch, T., Jayne, J. T., Miyoshi, T., Shimono, A., Hatakeyama, S., Takegawa, N., Kondo, Y., Schneider, J., Drewnick, F., Borrmann, S., Weimer, S., Demerjian, K., Williams, P., Bower, K., Bahreini, R., Cottrell, L., Griffin, R. J., Rautiainen, J., Sun, J. Y., Zhang, Y. M., and Worsnop, D. R.: Ubiquity and dominance of oxygenated species in organic aerosols in anthropogenically-influenced Northern Hemisphere midlatitudes, Geophys. Res. Lett., 34, L13801, doi:13810.11029/12007GL029979, 2007. 